\title{
Terraces of the Ohře River in Žatec Area, Czech Republic: When Models of Holocene Fluvial Development Are Not Sufficient
}

\author{
Tomáš Matys Grygar ${ }^{1,2, * \mathbb{C}}$, Jitka Elznicová ${ }^{1} \mathbb{C}$, György Sipos $^{3}$ and Tímea Kiss ${ }^{3}$ \\ 1 Faculty of Environment, University J.E. Purkyně in Ústí nad Labem, Pasteurova 3632/15, \\ 40096 Ústí nad Labem, Czech Republic; jitka.elznicova@ujep.cz \\ 2 Institute of Inorganic Chemistry of Czech Academy of Sciences, 25058 Řež, Czech Republic \\ 3 Department of Geoinformatics, Physical and Environmental Geography, University of Szeged, \\ Egyetem u. 2-6, 6722 Szeged, Hungary; gysipos@geo.u-szeged.hu (G.S.); kisstimi@geo.u-szeged.hu (T.K.) \\ * Correspondence: grygar@iic.cas.cz
}

Citation: Grygar, T.M.; Elznicová, J.; Sipos, G.; Kiss, T. Terraces of the Ohře River in Žatec Area, Czech Republic: When Models of Holocene Fluvial Development Are Not Sufficient. Geosciences 2021, 11, 210. https:// doi.org/10.3390/geosciences11050210

Academic Editors:

Jesus Martinez-Frias and Luca Mao

Received: 23 March 2021

Accepted: 7 May 2021

Published: 12 May 2021

Publisher's Note: MDPI stays neutral with regard to jurisdictional claims in published maps and institutional affiliations.

Copyright: (c) 2021 by the authors. Licensee MDPI, Basel, Switzerland. This article is an open access article distributed under the terms and conditions of the Creative Commons Attribution (CC BY) license (https:/ / creativecommons.org/licenses/by/ $4.0 /)$.

\begin{abstract}
The development of the Ohře River near Žatec between the Late Glacial Maximum (LGM) and present time was studied to obtain its natural trajectory and thus to understand the role of human impact on floodplain development. The study was based on geomorphic research, sampling and dating fluvial sediments by optically stimulated luminescence (OSL) and anthropogenic contamination by Sn since 16th century. During the LGM and the Pleistocene/Holocene transition $(\mathrm{P} / \mathrm{H})$, the river valley was shaped by large, incising meanders creating the entire valley floor. The Holocene river, due to decreased channel forming discharges, only slowly continued the LGM and $\mathrm{P} / \mathrm{H}$ trajectory by cut-offs of the large palaeomeander necks and channel belt narrowing and incision. The last Holocene incision step was likely triggered by hydrological extremes of the Little Ice Age. The LGM and P/H Ohře River consequently changed from meandering to low sinuous, incised in the valley floor; this incision was completed by river engineering in the 20th century. The Ohře River development can thus be rationalised neither by traditional terrace-step formation model nor by model of the Anthropogenic aggradation.
\end{abstract}

Keywords: river systems; climate changes; climate extremes; fluvial response; anthropogenic impact

\section{Introduction}

One major aim of the recent floodplain studies has been to distinguish intrinsic (autocyclic and stochastic) and extrinsic (climatic, anthropogenic, and sometimes tectonic) triggers in the floodplain development, typically to isolate climatic and/or anthropogenic signals in fluvial sedimentary records [1]. The meta-analysis of ${ }^{14} \mathrm{C}$ ages, that is, the identification and dating of periods of elevated fluvial activity, is a prominent step in this direction. It is conducted by constructing probability density functions (PDFs) and searching for the relative cumulation of ages of certain floodplain sedimentary units/facies [2]. PDFs have been employed systematically by many teams to produce a considerable volume of age datasets, but the outputs are not always straightforward. Individual catchments and regions did not produce catchment-independent and supra-regional isochronous patterns attributable to the Holocene climate change. PDFs were challenged from a methodological (theoretical) aspect [3]. Further studies identified the mechanisms by which the expected straightforward climatic record in floodplain sediments is blurred, such as the catchment- or reach-specific impacts of microtopography, bedrock resistance, and fluvial (dis)connectivity [4-7]. Faust and Wolf [5] explicitly stated that meta-analyses using PDFs "are often accompanied by the release of the age data from their original (stratigraphic) context, and the data is often unreflectedly used and correlated across a variety of scales". Faust and Wolf [5] also noted that researchers commonly tend to limit the number of samples for dating, typically for economic reasons. However, under-sampling can produce biases, and resulting studies can confirm paradigms rather than reveal the real complexity 
of each studied fluvial system. Understanding river systems requires complete realization of their complexity, and conclusions must be based on careful field observations [1]. This requirement is contrasting with current under-representation of case studies in research publishing.

The need to respect the local settings to isolate climatic or anthropogenic impacts on floodplain patterns has been demonstrated in individual case studies [4,7-9]. For instance, the actual proportion of anthropogenic and climatic impacts on the development of middle-sized rivers in southeast Czech Republic, particularly the Morava River, has not been unequivocally distinguished, despite systematic and lasting research for several decades $[9,10]$. The fluvial record was more complicated than expected. The impact of autogenic processes has been considered in theoretical models of fluvial development. These focused on the spatial probability of sediment reworking [11], autogenic formation of terraces without exogenic forcing [12], impact of the slope processes on channel migrations [13], and impacts of variable discharge and sediment delivery on near-channel topography [14]. All of these aimed to visualise the consequences of theoretically known phenomena on the real floodplain topography. Autogenic processes and 'stochastic' sitespecific features in the studied river segments can substantially blur the climatic and anthropogenic signals occurring in floodplains. However, the fluvial archives are valuable for their research and applicability in reconstructing past environmental changes.

This study deals with the Lower Ohře River valley in the Czech Republic (Figure 1). This portion of the Ohře River and its entire lower reach does not show considerable recent aggradation $[15,16]$. However, the 'floodplain siltation' and similar consequences of aggradation have frequently occurred in European rivers in catchments under anthropogenic pressure [17]. The Ohře River has remarkable palaeomeanders in the study area (Figure 1), which have attracted researchers for at least one century [18-21]. Local authors [19-21] assumed that the river has produced a staircase (strath) terrace system with exactly one incision step per glacial cycle $[19,20]$. It was later recognised that the real number of incision steps per glacial cycle could differ [22,23], and all those steps need not be preserved [13,23]. Numerous studies have documented departures from a simple historical model of the strath-terrace formation, caused by the sediment reworking in cut-and-fill terraces and palaeochannel belts in paraglacial river valleys [24-26], polycyclic terraces [27], impact of the bedrock on terrace distribution and parameters [28], and upstream propagation of terrace formations due to changes in the erosion base in the lower reach [29]. These findings should prompt researchers to revisit preceding case studies of fluvial terraces that were not supported by the sediment dating, as shown by several European rivers by [30].

Recent optically stimulated luminescence (OSL) dating showed that the palaeomeanders of the Ohře River downstream of Žatec were formed in the Holocene [16] rather than the Pleistocene, as expected earlier [21] and specified in actual maps by the Czech Geological Survey (CGS). We have continued the critical revisiting of models for the Ohře River development initiated by Elznicová et al. [16] by increase of the OSL dating points, more extensive use of contamination dating for sediments younger than five centuries [31-33], and identification of major changes in the fluvial patterns in the study area. The palaeomeanders of the Ohře River offer unexplored opportunities to understand the river behaviour during the Holocene, including periods of expected human inherence. We focused on the $\mathrm{P} / \mathrm{H}$ transition and Holocene evolution of the Ohře River in the Žatec area. The research questions that our work seeks to answer are: (1) did site-specific phenomena act in the study area, or did the development follow known scenarios? and (2) has the Holocene river development changed in the in the period of anthropogenic impact? 

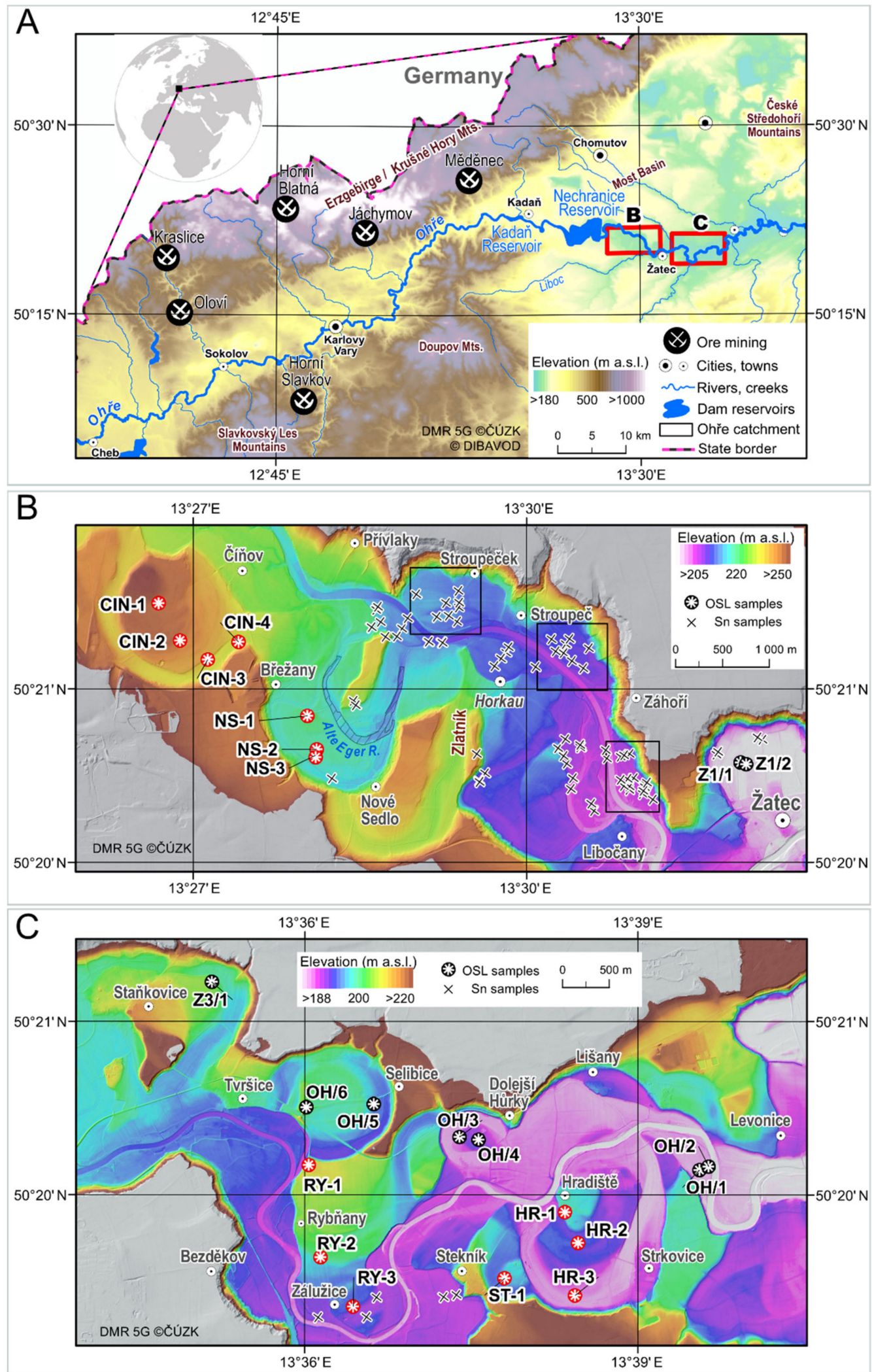

Figure 1. Maps of the Ohře River catchment with major ore regions and mountains (A). Detailed DTM and position of OSL sampling sites in the areas upstream (B) and downstream Žatec (C). Position of areas in panels B and $C$ is shown by red rectangles in panel A. 


\section{Study Area and Methods}

\subsection{Study Area}

\subsubsection{Geological Settings}

The Ohře River catchment has varied geology and geochemistry. The uppermost reach, partly in eastern Germany, is covered by metamorphic rocks with a chemical composition close to the mean upper continental crust (UCC; [15]). The middle reach includes several geological and geochemical anomalies. Granite plutons of the Late Palaeozoic age occur in the river catchment near Karlovy Vary and in Slavkovský Les Mountains. Ore regions have occurred in both these areas since the late Mediaeval times [15,32]. Greisen rocks with ore veins are frequent in the Krušné Hory Mountains [32]. Further downstream, the river is incised into the Oligocene and Miocene basaltic rocks of the Doupov Mountains [15]. The Doupov Mountains are a remnant of the Oligocene basalt floods of the České Středohoři Mountains. This was followed by the Miocene subsidence and fluviolacustrine deposition in the Cheb, Sokolov, and most basins of the Ohře Rift [34]. These Miocene sediments represent the bedrock of the Ohře River in the studied area near Žatec [16]. Moreover, the Ohře Rift development has also been responsible for the formation of the Ohře River network [19].

\subsubsection{Valley Morphology: Terraces}

The Ohře River terraces were first described scientifically about a century ago [18]. The age model for terraces was proposed by Balatka and Červinka [19]. Tyráček [20] attempted to use palaeomagnetic dating of porcelanite for supporting the terrace model; he used clay beds in coal seams that were fired by the self-ignition of the coal in the outcrops. The results were promoted in international literature [21]. The terrace stratigraphy by Balatka and Červinka [19] assumed a regular step-like incision in each subsequent climatic cycle. This reportedly produced as much as 24 terrace levels in a total elevation range of $<100 \mathrm{~m}$, that is, ca. $4 \mathrm{~m}$ per terrace. Balatka and Červinka [19] as well as Tyráček [20,21] assumed that the terraces represented the entire Quaternary period.

Previous studies $[19,20]$ provide a valuable summary of preceding geological mapping and research, including the palaeopedology and archaeology. It indicated the middle Pleistocene age for the higher terrace levels; in particular, $>250 \mathrm{~m}$ a.s.l. in the Čínov area and $>230 \mathrm{~m}$ a.s.l. in the Staňkovice area. This is several tens of metres above the levels addressed in this work. However, the ages of the terraces in the lower levels $(<210 \mathrm{~m}$ a.s.l.), which have been determined by Elznicová et al. [16], are much less than the previously assumed value.

In our work, the fluvial forms along the Lower Ohre River were studied in detail, downstream of the Nechranice Reservoir in the Žatec area (Figure 1). Though the valley is $80 \mathrm{~m}$ deep, only the youngest fluvial features were studied, which are located within $30-40 \mathrm{~m}$ elevation above the valley floor. These lower surfaces were classified as development stages. In some cases, they were considered equal to conventionally defined strath terraces. Their numbering was taken from Elznicová et al. [16]. Their characteristic features and definitions are presented in Table 1 and shown in Figures 2 and 3, respectively.

\subsubsection{Anthropogenic Impacts}

The entire Ohře River catchment has been intensively used by humans since prehistorical times, from the river valley to the montane regions. The Žatec area has settled since the Neolithic period. The archaeological findings in the Žatec area have been summarised by Holodňák [35]; commonly found are graves, ceramic vessels and shards, and tools from the Neolithic, Bronze Age, and younger periods. These settlements were found in the city of Žatec and practically in all historical villages. In level 0 of the floodplain, traces of pre-historic settlements are absent. In level I, they are exceptional, as that observed in site Horkau (in the historical SK map) or "ovčárna" (sheep farm) situated north of the Nové Sedlo village at $219 \mathrm{~m}$ a.s.l., which is $6 \mathrm{~m}$ above the current level 0a. Moreover, artefacts from slightly above the surrounding floodplain level show occupation from the Neolithic 
period to the 19th century. Other long-term settled sites at relatively low elevations above the floodplain are in Libočany (ca. $215 \mathrm{~m}$ a.s.l. and ca. $8 \mathrm{~m}$ above level 0a, i.e., at level II). Another persistently occupied region was the Staňkovice village at the slope of the palaeomeander II core. Other archaeological findings were identified at higher terraces.

Table 1. Fluvial forms and surface sediments in development stages or terrace levels. Number of OSL ages in the stages in parentheses, and elevation of the surfaces relative to the lowest surface of the active floodplain 0a. The number of OSL ages includes both this work and work by Elznicová et al. [16]. Channel widths are in form of mean (error), n.p. stands for genuine meanders not present. Footnotes: ${ }^{1}$ upstream Žatec, ${ }^{2}$ downstream Žatec.

\begin{tabular}{|c|c|c|c|c|}
\hline $\begin{array}{l}\text { Level/ } \\
\text { Stage }\end{array}$ & Features of Channels and Surface Sediments & $\begin{array}{l}\text { Age (Number } \\
\text { of OSL Ages) }\end{array}$ & $\begin{array}{c}\text { Relative } \\
\text { Elevation (m) }\end{array}$ & $\begin{array}{l}\text { Channel Width/ } \\
\text { Meander Radii (m) }\end{array}$ \\
\hline $0 \mathrm{a}$ & $\begin{array}{l}\text { Current channel belt, in places engineered, laterally stable or } \\
\text { wandering channel (no meandering), coarse-grained sediments } \\
\text { (no silts), deepest incised meander belt (Figure } 2 \text { and Figure 5) }\end{array}$ & 20th century & 0 & $\begin{array}{l}64(10) / \text { n.p. } \\
54(9) / \text { n.p. }\end{array}$ \\
\hline $0 \mathrm{~b}$ & $\begin{array}{l}\text { Subrecent (pre-engineered) channel belt, with lateral deposits covered } \\
\text { by overbank fines, Sn-contaminated, laterally reworked overbank } \\
\text { sediments, wandering channel, e.g. Libočany SK (Figure 5B) }\end{array}$ & $\begin{array}{l}\text { Post-16th century } \\
\text { (2) }\end{array}$ & $0-3$ & $\begin{array}{l}85(13) / \text { n.p. }{ }^{1} \\
72(9) / \text { n.p. }\end{array}$ \\
\hline $0 \mathrm{c}$ & $\begin{array}{l}\text { Subrecent (pre-engineered) channel belt, with uncontaminated } \\
\text { channel deposits covered by Sn-contaminated overbank fines or } \\
\text { channel fills, laterally reworked overbank sediments, wandering } \\
\text { channel (Figure 5B) }\end{array}$ & Pre-16th century (2) & $0-3$ & \\
\hline Ip & $\begin{array}{l}\text { Channel belts with transverse (passive) meanders, sandy deposits } \\
\text { covered by silty overbank fines, no Sn contamination, rather fine } \\
\text { sediments (sandy and silty), upstream Žatec, meanders at Nové Sedlo } \\
\text { I, Alte Eger, Libočany I. (Figure 1B, Figure 4, and Figure 6) }\end{array}$ & $\begin{array}{l}\text { Middle/Late } \\
\text { Holocene (4) }\end{array}$ & $2-4$ & 40-50/n.p. \\
\hline $\operatorname{Im}$ & $\begin{array}{l}\text { Genuine meanders of a small diameter abandoned by subsequent } \\
\text { incision of channel belt 0, downstream Žatec: Selibice, Dolejší Hůrky, } \\
\text { Stekník (Figure 1C, Figure 2B, Figure 3C, and Figure 6) }\end{array}$ & $\begin{array}{l}\text { Middle/Late } \\
\text { Holocene (5) }\end{array}$ & $2-5$ & $90 / 250$ \\
\hline IIm & $\begin{array}{c}\text { Channels with large incising (ingrown) meanders, coarse sediments } \\
\text { with sand matrix and pebbly admixtures, no silts, downstream Žatec: } \\
\text { Staňkovice, Rybňany-Zálužice, Hradiště-Strkovice, (Figure 1C, } \\
\text { Figure 2B, Figure 3C, and Figure 6) }\end{array}$ & LGM (6) & $5-7$ & $130-200 / 550-900$ \\
\hline IIm & $\begin{array}{l}\text { Incising (ingrown) meanders of a large diameter, coarse sediments } \\
\text { (coarse sand to cobbles), no silts, upstream Žatec: Číňov, Nové Sedlo II, } \\
\text { (Figure 1B, Figure 2B, Figure 3B and Figure 6) }\end{array}$ & LGM (3) & $10-20$ & $140-170 / 600-740$ \\
\hline III & $\begin{array}{c}\text { Figure 2A, terrace level above stage II, elevation parallel with current } \\
\text { channel belt, preserved mostly as flat strips around incised valley level } \\
\text { II, also tops of some meander cores of stage II, possibly remnants of } \\
\text { braided plain, around Žatec }\end{array}$ & Late Pleistocene (1) & $20-30$ & \\
\hline
\end{tabular}

The extent and character of the mediaeval colonisation of the ridges of the Krušné Hory Mountains (Erzgebirge in German), charcoal and glass production, and ore exploitation can be inferred from both the complex reconstruction of a nearby German montane site, Ullersdorf [36], and the extensive contamination of the Ohře River channel sediments [32]. Large-scale deforestation for charcoal produced for glass making and metallurgy changed the local plant cover dominated by broad leaved trees in the Krušné Hory Mountains into secondary forests dominated by spruce.

The locations of the major ore regions in the Ohře River catchment are shown in Figure 1A. The ore veins in the Slavkovský Les and Krušné Hory mountains have likely been exploited from prehistoric times, but the most extensive exploitation occurred in the 16th century for ores bearing $\mathrm{Ag}, \mathrm{Cu}, \mathrm{Pb}$, and $\mathrm{Sn}[32,33,37]$. The Ohře River system has consequently been contaminated mainly by $\mathrm{As}, \mathrm{Cu}, \mathrm{Pb}, \mathrm{Sn}$, and $\mathrm{Zn}[32,33,37]$. Among these elements, $\mathrm{Sn}$ is the least mobile after sediment deposition, and we thus consider it as the most reliable marker of sediments younger than the mining peak $[16,31]$. 

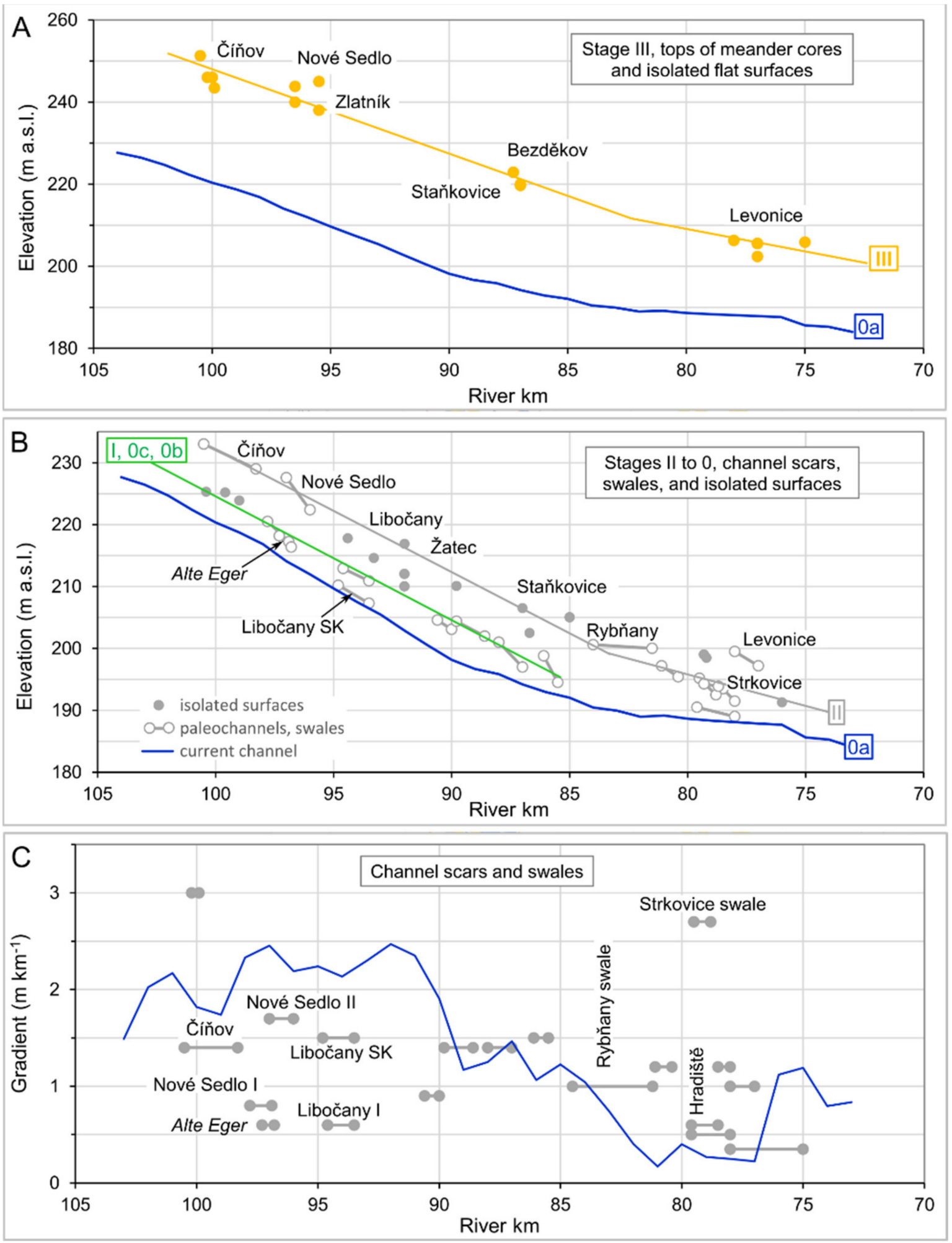

Figure 2. Longitudinal elevation profiles of current channel and prominent flat surfaces in fluvial stage III (A). Elevation profiles of current channel, palaeomeander scars, swales in meander cores, and isolated remnants of flat surfaces of stages 0, I and II (B). The slopes of active channel and palaeochannels (in \%o, or $\mathrm{m} \mathrm{km}^{-1}$ ) estimated from current DTM (C). All elevations and slopes were projected to river $\mathrm{km}$ of the current channel perpendicularly to the valley axis. Žatec is in the 90 th river $\mathrm{km}$. 

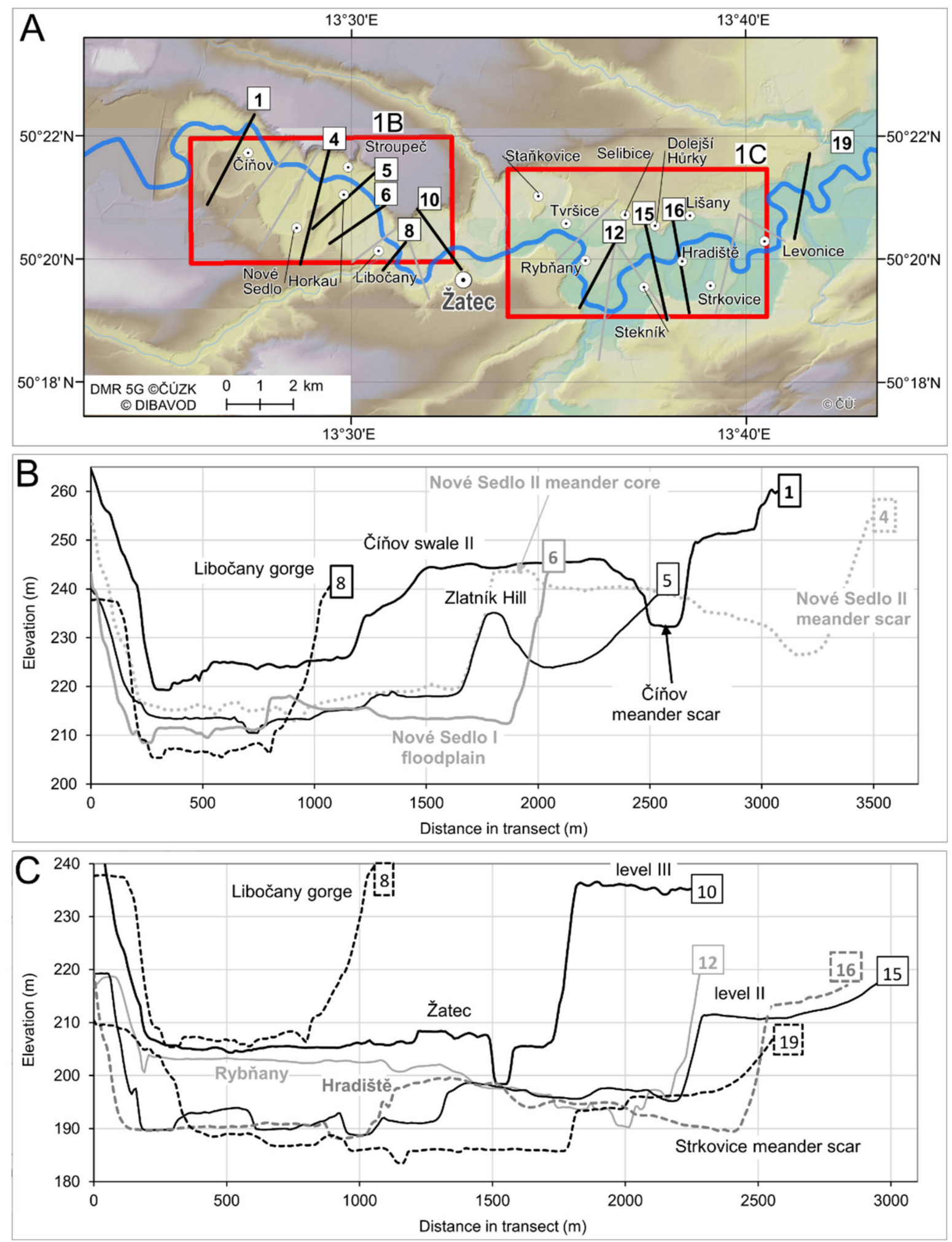

Figure 3. Elevation transects through the river valley in positions shown in panel A. Red rectangesl in panel A shows areas depicted in Figure 1B,C. Definition of terrace levels/development stages upstream (B) and downstream Žatec (C). Labels of terrace levels and meander names are listed in Table 1. 


\subsection{Methods}

\subsubsection{GIS Analysis}

The geomorphology of the study areas was described using a field survey and a digital terrain model (DTM) derived from the laser scanning (LiDAR) dataset of 2010 (DMR 5G, Czech Office for Surveying, Mapping and Cadastre, ČÚZK). Data processing, analysis, and visualisation were conducted in ArcGIS Desktop 10.7, with the 3D Analyst extension (ESRI, USA). Geomorphological development phases were identified based on the study by Elznicová et al. [16]; these included the terraces, incised (palaeo)meanders, and palaeochannels occasionally preserved on the valley floor. The individual elevations/ages distinguished in the topography were denoted as development phases and numbered from the active channel belt (0) upwards (I to III). More channel generations were identified in stage 0 and indicated by letters, from actual $(a)$ to older $(b, c)$. Segments in development stage I were further classified for active (Im; circular, regularly developing meanders) and passive meandering (Ip; transverse and low-sinuosity channels).

The hydrological/geographical datasets on the channel and active floodplain (digital basis of the water management data, DIBAVOD) were purchased from the T. G. Masaryk Water Research Institute (Prague). Based on this dataset and DTM, the channel elevation and valley width of the Ohře River were calculated using ArcGIS. The main historical maps - the Imperial Obligatory Imprints of the Stable Cadastre (SK maps) produced in the 1840s were purchased from the ČÚZK.

\subsubsection{Geochemical Analyses}

The elemental composition of the sediments, which were derived from the youngest floodplain in its development stages, was determined by X-ray fluorescence spectrometry (XRF). We conducted laboratory analyses of the sampled sediments and in-situ analyses of drill cores directly in the field. Sediments were obtained by manually operated soil corers (groove corer with an internal diameter $3 \mathrm{~cm}$, from Eijkelkamp, Giesbeek, The Netherlands), which could be used in sediments ranging from coarse sand to clayey mud with negligible contents content of clasts with diameters of ca. $5 \mathrm{~mm}$ or large. In-situ analyses were conducted using either a Niton XL3t 950 GOLDD+ instrument (Thermo Scientific, Waltham, MA, USA) or a DELTA Premium (Olympus Innov-X, Waltham, MA). Both instruments comprise energy dispersive, Peltier cooled large-area Si drift detectors and a pre-installed software for the quantitative analysis of geological samples. The performance of the insitu XRF analyses was demonstrated [38] for U and Zn contamination in another Czech floodplain. Tin concentrations below the limit of detection (LOD) of the two instruments in our study were estimated from the error values produced by the quantitation software extrapolated to low concentrations. The lowest values produced by XRF (LOD) were 16 and $38 \mathrm{mg} \mathrm{kg}^{-11}$ for the Niton and DELTA instruments, respectively. Whereas, the corresponding extrapolated error values were 10 and $13 \mathrm{mg} \mathrm{kg}^{-11}$; specifically, the LODs of the Niton and DELTA instruments showed approximately two-fold and three-fold errors, respectively. Sn concentrations greater than $50 \mathrm{mg} \mathrm{kg}^{-1}$ were considered to be potentially contaminated.

Selected sediment cores were brought to the laboratory in Institute of Inorganic Chemistry in Řež, and subsequently dried, powdered in a planetary micromill, and subjected to the XRF analysis using a desktop instrument Epsilon 3X (Panalytical, Almelo, The Netherlands) with a Peltier-cooled large-area Si detector (SDD, an energy dispersive detector). The device was calibrated using the certified reference materials, as described previously [33].

The mean concentration of $\mathrm{Sn}$ in the UCC is $2.1 \mathrm{mg} \mathrm{kg}^{-1}$ [39], but the local background for the Ohře River sediment is presumably higher due to ore veins and their weathering products in the river catchment of the Krušné Hory Mountains. The thresholds for contamination (Sn concentrations and thickness of the contaminated strata) were estimated using histograms and probability plots by following the generalised approach of Matschullat et al. [40], and applied to the contaminated sediments of the Ohře River [37]. 


\subsubsection{OSL Dating}

OSL sampling was conducted from shovel-dug pits that were 30-100 cm deep, with a thick black polyethylene foil cover over the pit and the sampling person. From coarse, gravelly sediments (typical for point bars of large and incising meanders), fine sand was obtained from the matrix among clasts. In finer lithologies deposited by laterally unstable channels, deposits containing sand were obtained from drill holes made by a soil auger with using PVC tubes.

The 150-220 $\mu \mathrm{m}$ grain size fraction was used for the OSL measurements in University of Szeged. The preparation of samples followed standard techniques [41,42]. Although multi-grain aliquots were used during the measurements, sample size was kept low ( 20-30 grains/aliquot) in order to be able to capture the scatter of data in relation with partial bleaching and potential post-depositional mixing. Measurements were carried out with a RISØ TL/OSL-DA-20 automated luminescence reader, using blue LED simulation and a Hoya U340 optical filter. Radioactive irradiation was conducted using a calibrated ${ }^{90} \mathrm{Sr} /{ }^{90} \mathrm{Y}$ $\beta$-source. Equivalent doses (De) were determined using a single aliquot regeneration (SAR) protocol $[43,44]$.

The OSL intensities were fitted using a single saturating exponential function. Data processing procedures, such as the rejection criteria for selecting acceptable aliquots, identification of feldspar contamination in quartz extracts, and the calculation of aliquot De values are described by Elznicová et al. [16]. Sample De was calculated using either the central age model (CAM), the minimum age model (MAM), or the finite mixture model (FMM) [45]. When selecting between CAM and MAM, decision was made on the basis of the skewness and overdispersion of De values. However, in terms of 3 samples the distribution of single aliquot De values showed two very distinct peaks, in these cases the FM model was applied and two separate sample De results were given.

The environmental dose rate $\left(D^{*}\right)$ was measured using a high-resolution, extendedrange gamma-ray spectrometer (Canberra XtRa Coaxial Ge detector). Dry dose rates were calculated from the conversion factors of Liritzis et al. [46]. The attenuation factors for the $\beta$ dose rates were obtained from [47]. Wet dose rates were assessed based on the in-situ water content [48]. The rate of cosmic radiation was determined based on burial depth, following the equation of Prescott and Hutton [49].

\section{Results}

\subsection{Geomorphic Description}

The actual channel slope upstream of Žatec (Figure 1B) varies between 1.5 and $2.5 \mathrm{~m} \mathrm{~km}^{-1}$ (Figure 1C, Figure 2). However, the historical channel slope was lower as the result of the high sinuosity of palaeomeanders. Downstream of Žatec, the active channel slope decreases to $\sim 0.5 \mathrm{~m} \mathrm{~km}^{-1}$ in average. The slope remains low further downstream [16].

The river valley floor (elevation up to ca. $10 \mathrm{~m}$ above the active floodplain 0a, Figure 2) is currently $1000-1500 \mathrm{~m}$ wide upstream of Libočany and ca. $1000 \mathrm{~m}$ wide downstream of Žatec (Figure 3). The "bottleneck" of the valley floor is near Libočany, where the valley floor became significantly narrower, as its width is only $700 \mathrm{~m}$ (Figure 3 , cross section 8 ). This narrow valley section plays an important role in the fluvial processes, as it can substantially influence the flow conditions upstream and downstream.

Based on the topography (e.g. Figure 1B,C) and elevation transects drawn roughly perpendicularly to the valley axis (Figure 3), characteristic surfaces and form assemblages were identified. These represent fluvial stages labelled from 0 to III according to Elznicová et al. [16], and also presented in Table 1.

The uppermost studied surface (development stage) III is flat and longitudinally descending. It is located $20-30 \mathrm{~m}$ above the current channel (0a), running parallel to it. Surface III represents a possible fragmented surface of the strath-terrace level in a conventional sense (Figure 2A). Fragments of surface III are partly represented by small top parts of circular meander cores of stage II (Číñov, Nové Sedlo, Staňkovice, and Levonice), partly by irregular elongated hills scattered above the floodplain along the edges of the 
valley (Zlatník, Figures 3B and 4), and by flat remnants of a former floodplain without meander scars (Žatec, transect 10 on Figure 3C, and near Bezděkov).

Table 2. OSL ages from preceding paper [16]. Elevations of sampling sites above the active floodplain surface (stage 0a) are in the last column.

\begin{tabular}{ccccc}
\hline Field ID & Description & Location (Meander Name) & Age (ka) & Elevation (m) \\
\hline Z3/1 & Last point bar of a big palaeomeander & Staňkovice & $2.91 \pm 0.31$ & 6 \\
\hline OH6 & Core of cut-off palaeomeander & Selibice & $12.39 \pm 0.70$ & 4 \\
OH5 & Last point bar of preceding & Dolejší Hůrky & $2.16 \pm 0.43$ & 3 \\
\hline OH4 & Core of cut-off palaeomeander & $1.94 \pm 0.28$ & 2 \\
OH3 & Last point bar of preceding & & $1.26 \pm 0.17$ & 2 \\
\hline
\end{tabular}

Table 3. OSL ages and Sn contamination in the OSL sampling sites. Age models for OSL: CAM Central Age Model, MAM Minimum Age Model, FM Finite Mixture Model. Elevations relative to the active floodplain surface (stage 0a) are in the last column. Sites are ordered in downstream direction.

\begin{tabular}{|c|c|c|c|c|c|c|c|}
\hline Field ID & Lab. ID & Location (Meander Name) & Depth (cm) & Age Model & Age (ka) & Sn Contamination & Elevation (m) \\
\hline CIN-1 & OSZ 1830 & \multirow{3}{*}{ Číňov } & 50 & CAM & $36.50 \pm 2.89$ & N.A. & 25 \\
\hline CIN-2 & OSZ 1831 & & 50 & MAM & $0.71 \pm 0.13$ & N.A. & 22 \\
\hline CIN-3 & OSZ 1832 & & 50 & MAM & $0.43 \pm 0.08$ & No & 13 \\
\hline \multirow{2}{*}{ NS-1 } & \multirow{2}{*}{ OSZ 1833} & \multirow{3}{*}{ Nové Sedlo I } & \multirow{2}{*}{50} & FM1 & $2.77 \pm 0.20$ & \multirow{2}{*}{ N.A. } & \multirow{2}{*}{5} \\
\hline & & & & FM2 & $7.92 \pm 0.53$ & & \\
\hline NS-2 & OSZ 1834 & & 50 & MAM & $2.03 \pm 0.29$ & No & 3 \\
\hline \multirow{2}{*}{ RY-1 } & \multirow{2}{*}{ OSZ 1823} & \multirow{5}{*}{ Rybňany-Zálužice } & \multirow{2}{*}{50} & FM1 & $1.86 \pm 0.32$ & \multirow{2}{*}{ N.A. } & \multirow{2}{*}{12} \\
\hline & & & & FM2 & $21.13 \pm 1.77$ & & \\
\hline RY-2 & OSZ 1824 & & 50 & MAM & $15.71 \pm 1.86$ & N.A. & 9 \\
\hline \multirow{2}{*}{ RY-3 } & \multirow{2}{*}{ OSZ 1825} & & \multirow{2}{*}{50} & FM1 & $8.65 \pm 0.81$ & \multirow{2}{*}{ N.A. } & \multirow{2}{*}{2} \\
\hline & & & & FM2 & $19.20 \pm 2.27$ & & \\
\hline ST-1 & OSZ 1829 & Stekník & 50 & MAM & $1.32 \pm 0.15$ & N.A. & 7 \\
\hline HR-1 & OSZ 1826 & \multirow{3}{*}{ Hradiště-Strkovice } & 60 & CAM & $18.61 \pm 1.65$ & N.A. & 9 \\
\hline HR-2 & OSZ 1827 & & 70 & MAM & $22.22 \pm 2.02$ & N.A. & 6 \\
\hline HR-3 & OSZ 1828 & & 50 & MAM & $0.71 \pm 0.10$ & Yes & 0 \\
\hline LIB-13 & OST 2019 & Libočany I & 100 & MAM & $11.82 \pm 0.53$ & No & 3 \\
\hline NS-13 & OSZ 2023 & \multirow{4}{*}{ Nové Sedlo II } & 30 & MAM & $22.89 \pm 1.55$ & N.A. & 13 \\
\hline NS-14 & OSZ 2024 & & 50 & MAM & $19.03 \pm 1.79$ & N.A. & 21 \\
\hline NS_15 & OS7 2025 & & 70 & FM1 & $26.49 \pm 1.8$ & \multirow{2}{*}{ N.A. } & \multirow{2}{*}{21} \\
\hline NS-15 & USZ $20 \angle 5$ & & 70 & FM2 & $10.53 \pm 1.06$ & & \\
\hline NS-16 & OSZ 2026 & Alte Eger & 85 & MAM & $1.28 \pm 0.09$ & Yes & 3 \\
\hline
\end{tabular}

Stage II surfaces are mostly represented by abandoned incising (ingrown) palaeomeanders. They were formed by simultaneous lateral and vertical erosion, as discussed by Kiss et al. [50] for the Tisza River floodplain. The incising character of meanders in stage II is obvious from the descending meander core surfaces in the elevation transects shown in Figure 3 and Figure 6. Consistent with the incising character of stage II meanders, there are surfaces at elevations between levels II and I (Figure 2B).

The floodplain surface of fluvial stage I upstream of Žatec is flat and hosts the meander scars remaining after laterally unstable channels, frequently with abandoned loops (Nové Sedlo I, Alte Eger, and Libočany; Figure 1B, Figure 2B, Figure 3, and Figure 4). These channels have a nearly transverse direction relative to the valley axis. The Alte Eger (Old Ohře in German) was the active channel in historical times, as it is represented by the SK map (Figures 4 and 5). Its meander core is only about $1 \mathrm{~m}$ above the current floodplain 0a (Figure 4). The Alte Eger meander scar is still not filled by sediments, indicating channel activity until the recent past. The channel slope in this fluvial stage was much lower $\left(0.5-1.5 \mathrm{~m} \mathrm{~km}^{-1}\right.$ ) than the present (ca. $2 \mathrm{~m} \mathrm{~km}^{-1}$; Figure 2C). Neither of the boundaries 
between stages II, I and 0 are sharp, but consist of a continuum of individual levels (Figure 2B).

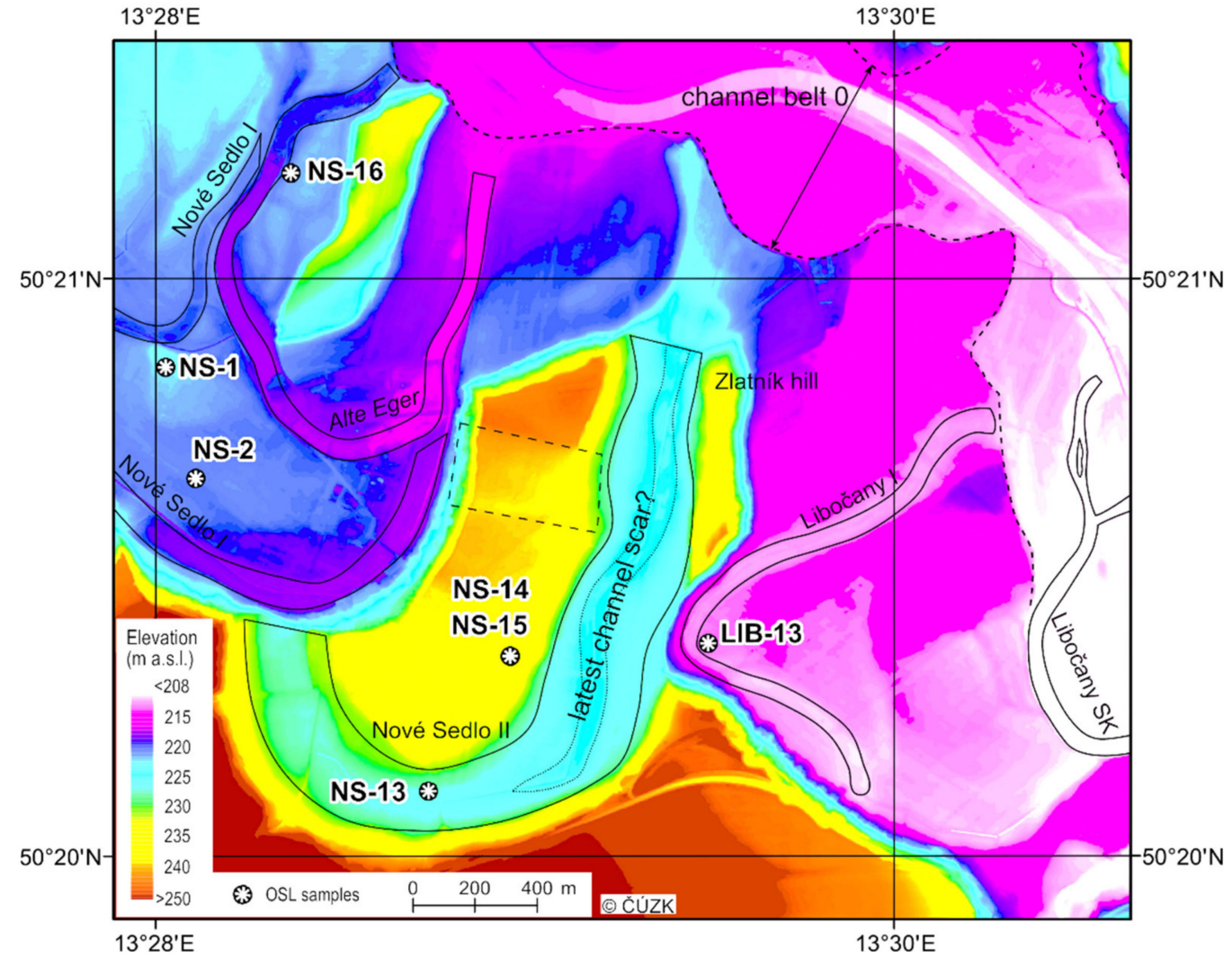

Figure 4. Detailed DTM with meander core and meander scar Nové Sedlo II (centre of figure) and abandoned channels Nové Sedlo I, Alte Eger, Libočany I, and Libočany SK, all outlined by black lines. Positions of OSL sampling sites are also shown, their ages are listed in Tables 2 and 3.

On the active floodplain (0) three channel belts were identified. The most recent channel belt $(0 a)$ has been shaped by river channel engineering, particularly by channel straightening and shortening in the 20th century. The engineering is particularly obvious in the channel topography upstream of Libočany (Figure 5B) and near Tvršice (Figure 5C). The original (pre-engineered historical) multi-channel system $(0 \mathrm{~b})$ is clearly discernible in the DTM upstream of Libočany (Figure 4). The deepest meander scars correspond to the channel position in the SK map from the first half of the 19th century. Dikes were constructed around the artificial 20th century channel (Figure 5D,E), mainly downstream of Žatec, to protect the villages, crop fields, and hop gardens in former palaeomeanders. Lateral channel movement near settlements and towns are prevented by revetment (Figure 5F). Based on their geomorphological setting and the applied dating methods, the fragments of an older channel belt (0c) were also identified. These palaeomeanders have been preserved at the distal parts of the active floodplain.

\subsection{OSL Ages}

From the study area some OSL ages were already published [16] and also used hereafter (Table 2). The new OSL ages of the Ohře River sediments are presented in Table 3. Based on the OSL data the timing of the formation of the levels described in Chapter 3.1. was determined. While the fluvial stage 0 a represents the modern channel belt, the palaeochannel belts of $0 \mathrm{~b}$ and $0 \mathrm{c}$ that are a few metres above $0 \mathrm{a}$ were formed in historical times. Stage I includes Middle to Late Holocene meandering channels and their floodplains; stage II denotes the large meanders formed around the $\mathrm{P} / \mathrm{H}$ transition; and stage III includes flat surfaces developed during the Late Pleistocene. 
To understand the development history of the valley, the OSL samples were collected from at least two points of the ingrown meanders (Figure 1B,C, Figure 6). The uppermost sample was taken from the rim of the meander core: here the point bar sediments represent the beginning of the incision phase. The lowermost sample usually represents the youngest (last) point bar of the palaeochannel, thus the end of the incision of a given form (or stage) could be determined. The timeframe for the development stages summarised in Table 1 was complemented by the information derived from the Sn contamination discussed in Sections 3.3 and 3.4.
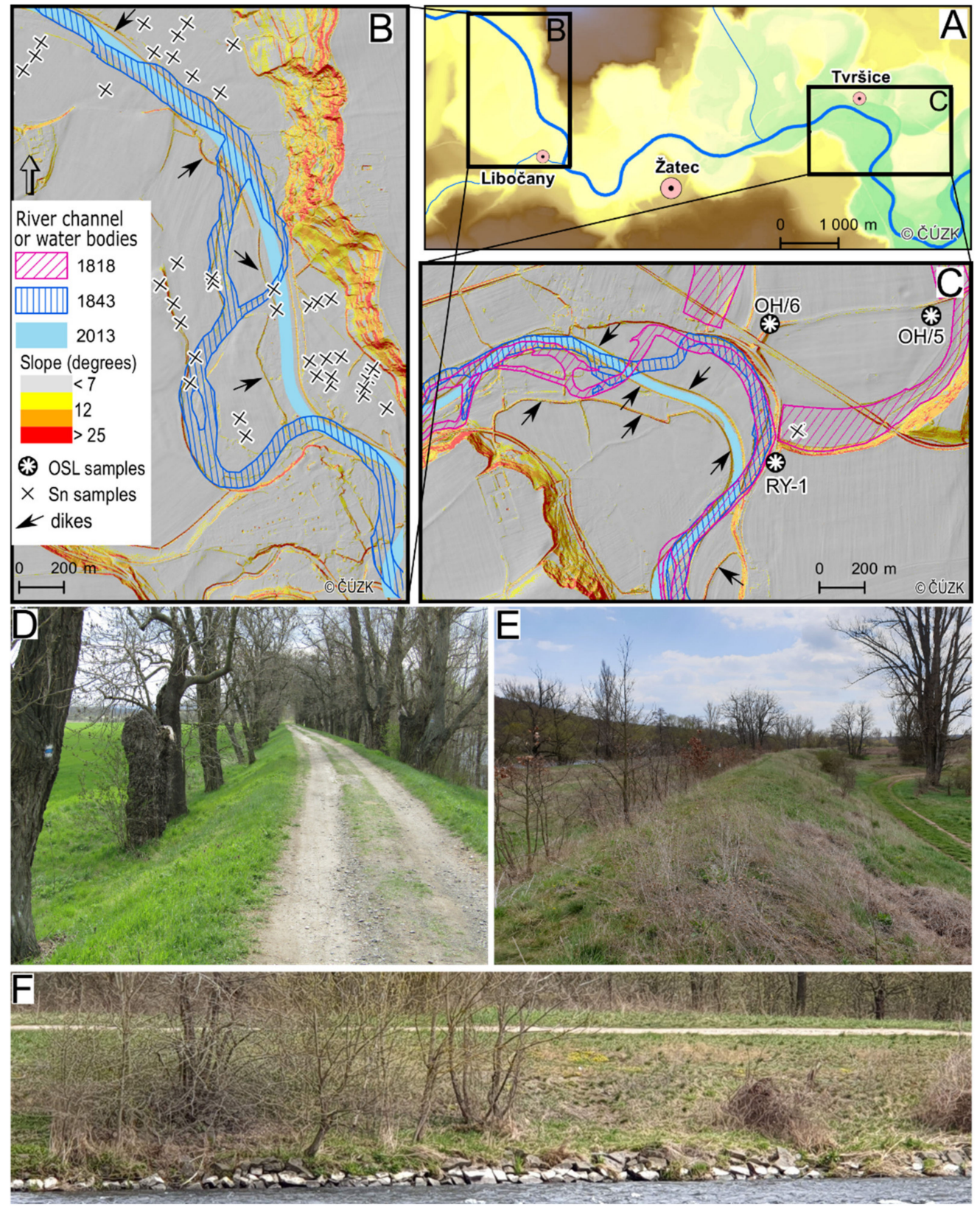

Figure 5. Examples of channel engineering in stage 0a. Places of channel straightening around Žatec (A) west of Libočany (B) and near Tvršice (C). DTM is shown in elevations (A) or slope (B,C). Former ponds and channel position old maps are shown (C), dikes along modern channel are indicated by arrows $(\mathbf{B}, \mathbf{C})$ and shown in panels $\mathbf{D}$ (Sroupeček) and E (Libočany). Stone revetment in the bank opposite to the Libočany dike (E) is also shown (F). DTM is shown in elevations $(\mathbf{A})$ or sloppiness $(\mathbf{B}, \mathbf{C})$. 


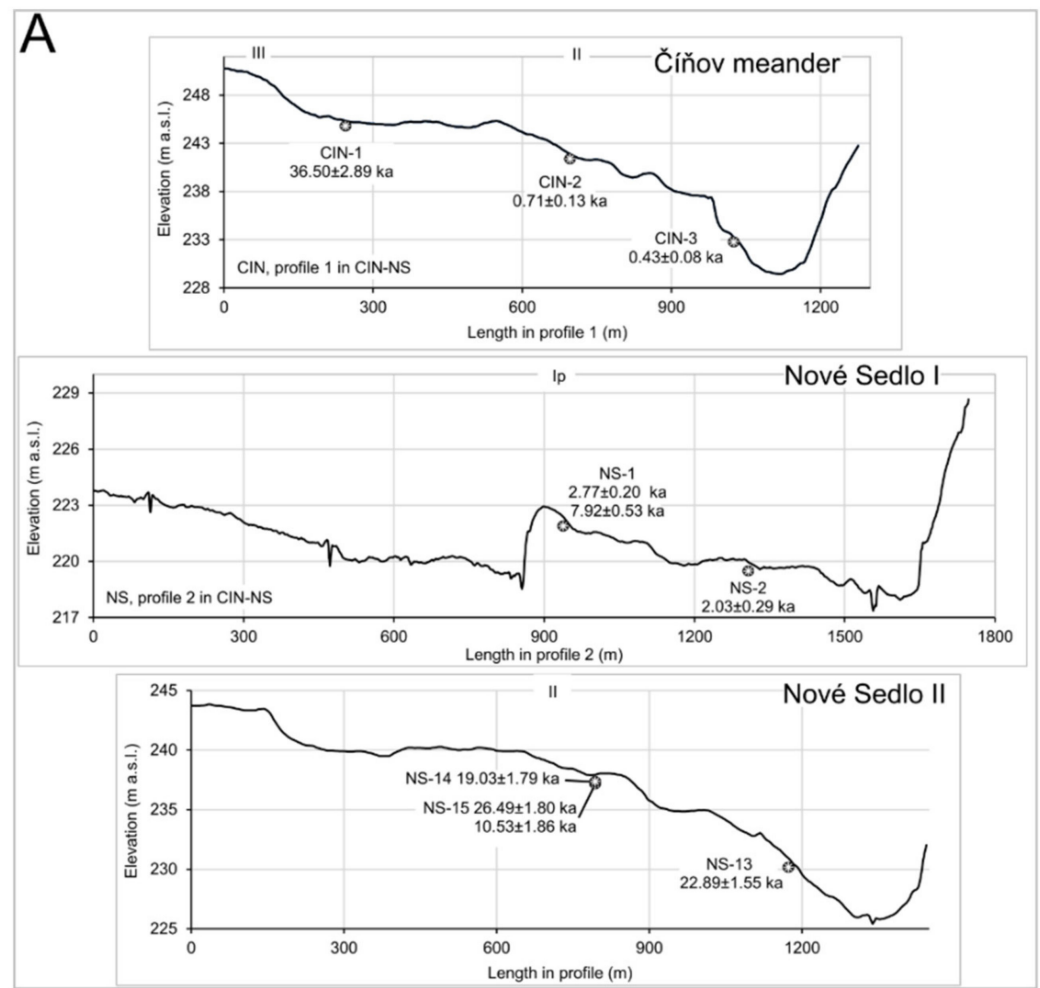

B
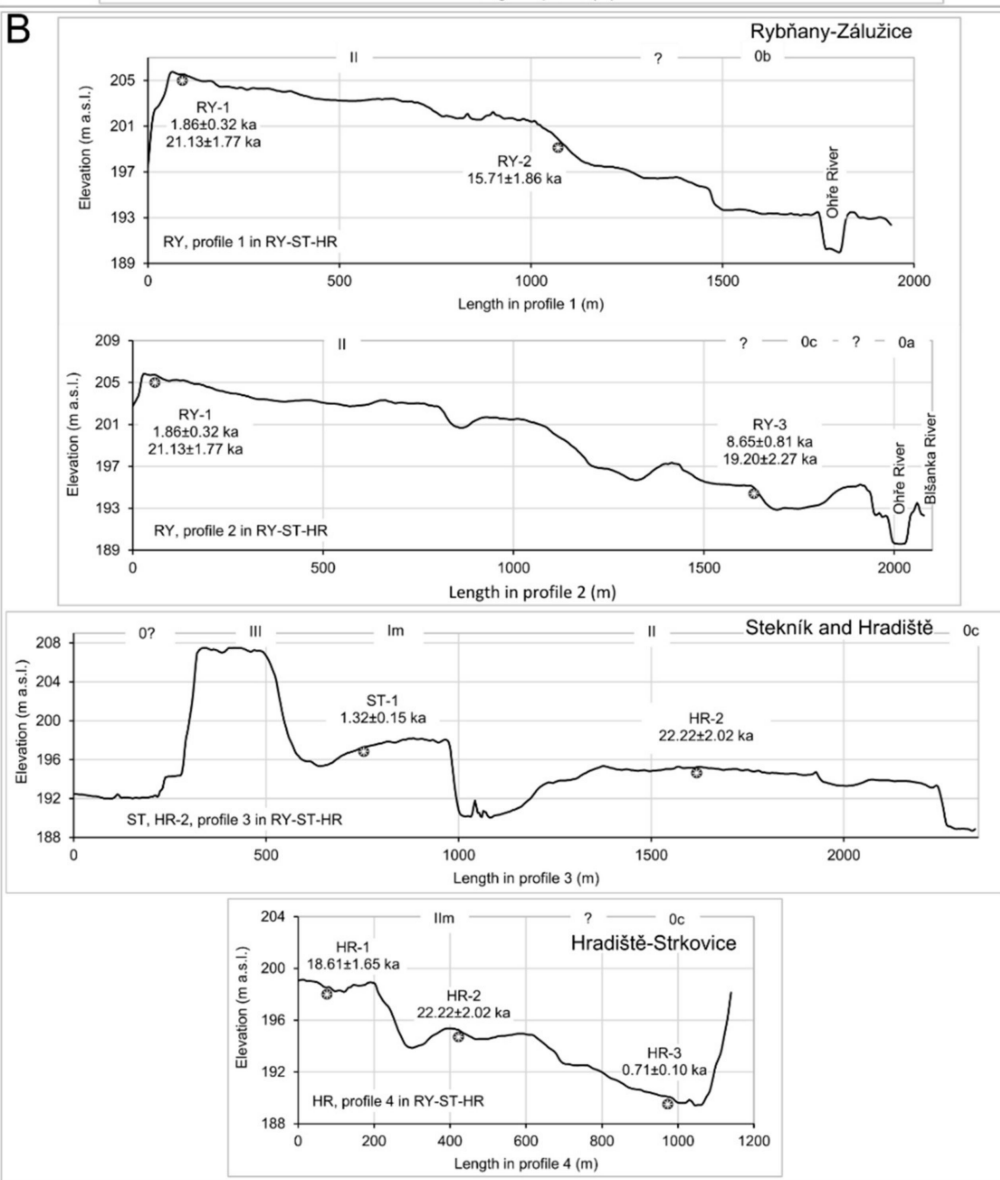

Figure 6. Elevation transects with OSL ages upstream (A) and downstream Žatec (B). Labels of terrace levels/development stages are listed in Table 1. 
The plot of elevation against OSL ages at the sampling sites (Figure 7) shows a general incision tendency of the river valley floor since (at least) the Last Glacial Maximum (LGM; terminated 19-20 ka). The oldest age yet obtained, $36.50 \pm 2.89 \mathrm{ka}$ at the top of the Čínov meander core (CIN-1), fits the same trend.

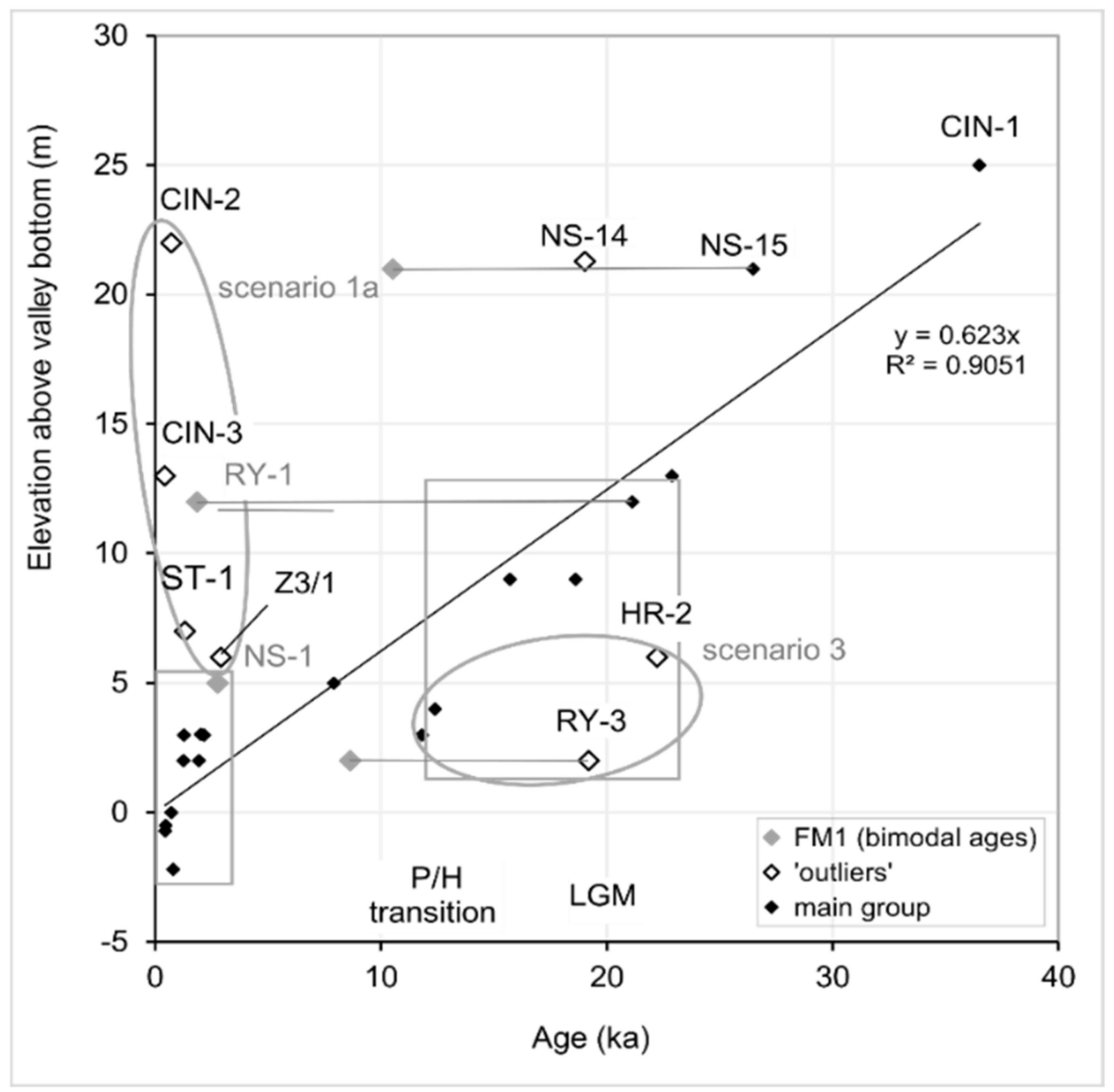

Figure 7. The OSL ages plot against elevation above the lowest floodplain level 0a, or 0b. OSL ages were taken from previous (Table 2) and actual works (Table 3).

\subsection{Sediment Geochemistry}

The geochemistry of the sediments in the valley floor was investigated for (1) Sn contamination by historical mining and (2) markers of the sediment provenance such as $\mathrm{K} / \mathrm{Rb}$ known from studying the Miocene sediments of the Most Basin [51] and recent Ohře River sediments [15]. Contamination by $\mathrm{Sn}$ was found in the lowermost floodplain levels (0a and $0 \mathrm{~b}$ ), and only exceptionally in the 0c meander scars (Table 1 ).

A histogram of the Sn concentrations in the studied sediments obtained by laboratory $\mathrm{XRF}$ is shown in Figure 8A. The major Sn concentration mode centred at ca. $8 \mathrm{mg} \mathrm{kg}^{-1}$ is ascribed to uncontaminated sediments (slightly above the UCC), while values above ca. $20 \mathrm{mg} \mathrm{kg}^{-1}$ are attributed to contamination. The main Sn-contamination mode was centred at $250 \mathrm{mg} \mathrm{kg}^{-1}$. In majority of the examined Ohře River sediments, Sn concentrations were indirectly proportional to the $\mathrm{K} / \mathrm{Rb}$ ratio (Figure $8 \mathrm{~B}$ ). However, several sediment samples showed increased $\mathrm{Sn}$ concentrations at a relatively high $\mathrm{K} / \mathrm{Rb}$ ratio, i.e., the $\mathrm{Sn}$ concentrations and $\mathrm{K} / \mathrm{Rb}$ ratios were probably not directly interrelated, but their change in the Ohře River sediments was temporally close. Three groups of sediments can thus be distinguished (Figure 8B): uncontaminated (low Sn), Sn-contaminated with $\mathrm{K} / \mathrm{Rb}<120$, and $\mathrm{Sn}$-contaminated with $\mathrm{K} / \mathrm{Rb}>120$. The variability of $\mathrm{K} / \mathrm{Rb}$ was not associated with the sediment lithology, as no relationship between $\mathrm{K} / \mathrm{Rb}$ and $\mathrm{Al} / \mathrm{Si}$ was found; the latter is a versatile proxy for the sediment grain size. 

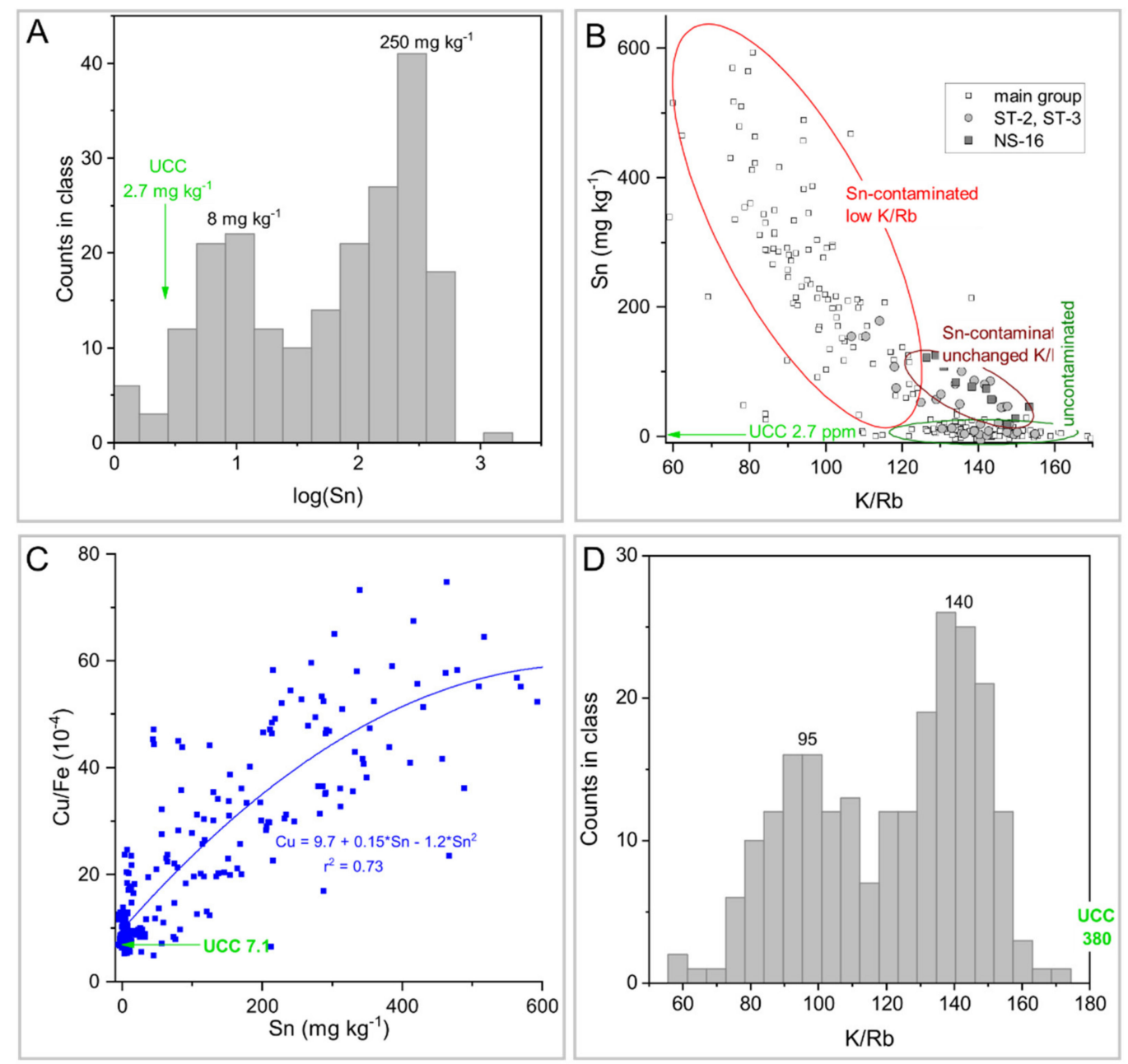

Figure 8. Stack of geochemical characteristics. Histogram of $\mathrm{Sn}$ concentrations with modal maxima (A), the relation between $\mathrm{Sn}$ and $\mathrm{K} / \mathrm{Rb}(\mathbf{B})$, correlation of $\mathrm{Sn}$ and $\mathrm{Cu}(\mathbf{C})$, and histogram of $\mathrm{K} / \mathrm{Rb}(\mathbf{D})$. UCC values are in green ink and arrows to corresponding axes.

The $\mathrm{K} / \mathrm{Rb}$ histogram shows two main modes: one centred at 100 and another at 140 . Both values are substantially lower than the global average (K/Rb in the UCC is 280; [39]). The low $\mathrm{K} / \mathrm{Rb}$ values in the studied sediments are a consequence of geochemical anomalies in the Ohře River catchment. Low values of $\mathrm{K} / \mathrm{Rb}$ have also been found in two sediment sources of the Ohře River in the study area: the Miocene Most Basin sediments $(\mathrm{K} / \mathrm{Rb}$ of 100-150, [52]) and the Rolava River sediments (100-140, [15]). The Rolava River is a tributary of the Ohře River with granitic rocks in its catchments [15]. In the lower reach of the Ohře River, where the geogenic anomalies in the upper and middle reaches of the river catchment are compensated by mixing with the Cretaceous and Quaternary sediments, the $\mathrm{K} / \mathrm{Rb}$ values range from 250 to 300 [15], which is much closer to the UCC value. The indirect proportionality of $\mathrm{Sn}$ and $\mathrm{K} / \mathrm{Rb}$ in the Žatec area (Figure $8 \mathrm{~B}$ ) is interpreted to be due to the mixing of Sn-rich and extremely low $\mathrm{K} / \mathrm{Rb}$ materials, presumably those from the Krušné Hory ore regions (Figure 1A), and some local uncontaminated material with low $\mathrm{K} / \mathrm{Rb}$ ratios. The minority pattern of the sediments labelled "Sn-contaminated, unchanged $\mathrm{K} / \mathrm{Rb}^{\prime}$ in Figure $8 \mathrm{~B}$ deserves particular attention as they were not scattered over the floodplain or within the depth profiles, and almost all were found in the proximal floodplain of Alte Eger (NS-16) and the distal floodplain in the hop garden near Stekník (ST-2 and ST-3).

Concentrations of $\mathrm{Sn}$ are elevated in conjunction with those of $\mathrm{Cu}, \mathrm{Pb}$, and $\mathrm{Zn}$ (only $\mathrm{Cu} / \mathrm{Fe}$ vs. Sn is shown in Figure 8C), which supports their attribution to ore mining and 
processing in the Ohře River catchment. The $\mathrm{Cu} / \mathrm{Fe}$ ratio is plotted in Figure $8 \mathrm{C}$ instead of the raw $\mathrm{Cu}$ concentration to minimise the grain-size control of the sediment contamination by potentially mobile divalent metals [53]. Mining of Sn and other metal ores in the Ohře River catchment peaked in approximately the same period (16th century) for all the mined metals. Their concentration depth profiles are similar, although each of the exploited metals $(\mathrm{Cu}, \mathrm{Sn}$, and $\mathrm{Pb})$ was present in specific minerals and distinct ore regions [32,37]. For instance, $\mathrm{Cu}$ was mined near Kraslice, $\mathrm{Pb}$ near Oloví, and $\mathrm{Sn}$ in all other ore regions, as shown in Figure 1A.

Typical depth profiles of Sn concentrations in the fine Ohře floodplain sediments sampled by the grove corer are shown in Figure 9. The entire thickness of these sediments was contaminated by $\mathrm{Sn}$ in the lowest-lying floodplain segments $0 \mathrm{a}$ and $\mathrm{Ob}$ (Figure 9C), particularly in the direct vicinity of the depressions of the abandoned channels. Weaker $\mathrm{Sn}$ contamination was limited to the surface sediment strata at level 0b (Figure 9B), probably due to contaminant dilution during floods, which levelled distal floodplain. In several exceptional cases, thick Sn-contaminated strata were found in abandoned channels of the development stages Ip (sediment fill of Alte Eger, drill cores Břežany-1, Břežany-2, and NS-16), and IIm (HR-3).

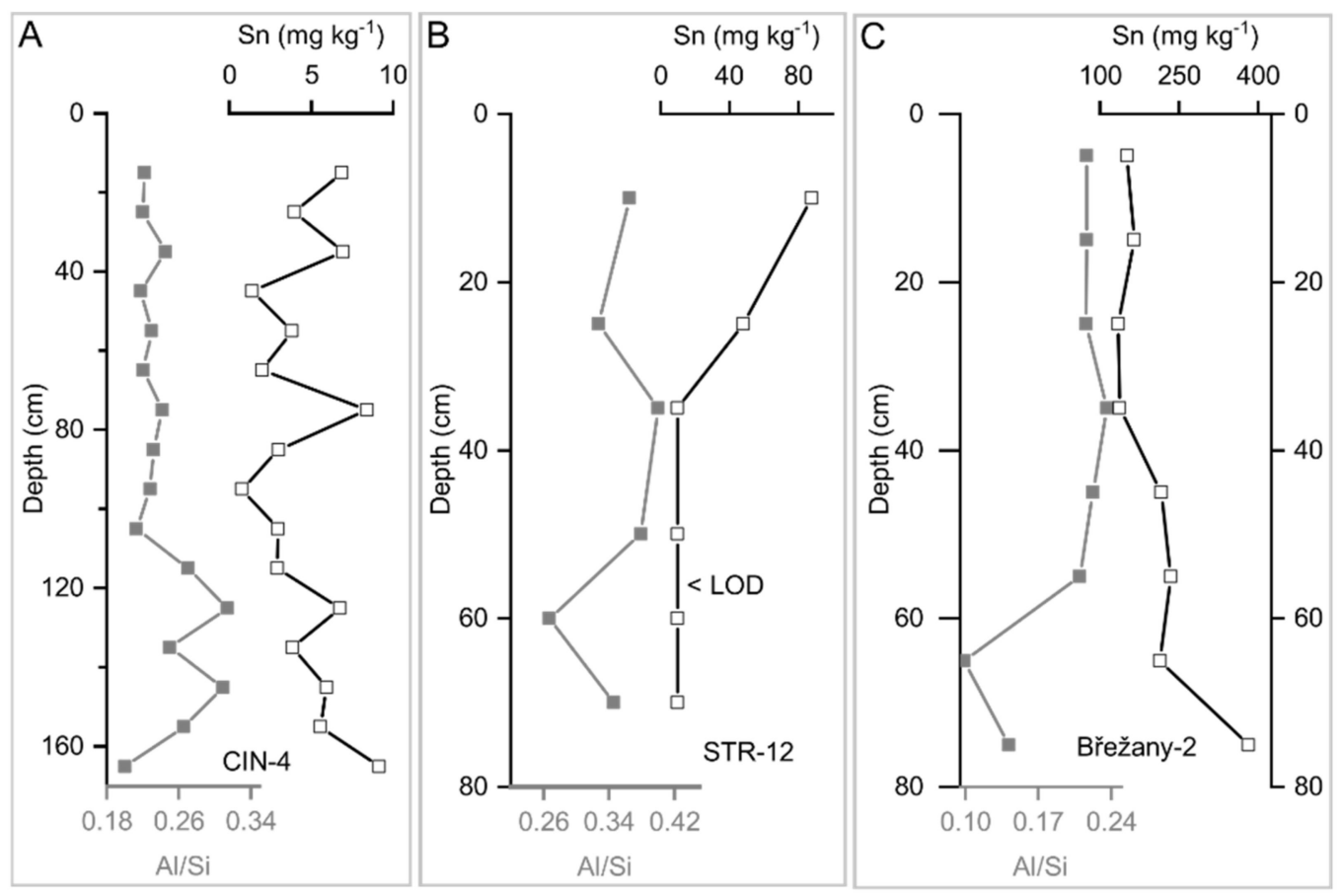

Figure 9. Typical depth profiles of Sn concentrations in uncontaminated strata of level II (A), weakly contaminated top stratum in level 0c (B), and contaminated fill of Alte Eger (C).

The Sn contamination facilitated the identification of OSL ages departing from the general trend shown in Figure 7. The Sn contamination was not identified in the CIN-4 sediment core (Figure 9A) in the fill of the Čínov palaeomeander scar, which is stratigraphically below the OSL-dated samples CIN-1, CIN-2, and CIN-3. We consider the lack of Sn contamination in CIN-4 to evidence its pre-16th century age, including the last channel fill (meander scar). This supports the young ages of CIN-2 and CIN-3 (Table 3, Figure 7) as evaluated by OSL is not primary, probably due to subsequent sediment reworking (scenario 1a, Table 4). 
Table 4. Possible Causes of Errors in OSL Ages.

\begin{tabular}{|c|c|c|c|c|}
\hline Problem & Scenario & Contra-Arguments, Doubts & Supportive Arguments & Action \\
\hline $\begin{array}{l}\text { Too young ages at } \\
\text { high elevations }\end{array}$ & $\begin{array}{l}\text { (1a) Recent } \\
\text { post-depositional mixing }\end{array}$ & $\begin{array}{l}\text { Fine mass between imbricated pebbles to } \\
\text { cobbles (channel armour) was sampled. } \\
\text { Recent surface processes have not been } \\
\text { sufficiently intensive to } \\
\text { rework/re-order clasts. }\end{array}$ & $\begin{array}{c}\text { Absence of } \\
\text { Sn-contamination in some } \\
\text { sediments with too young } \\
\text { OSL ages (CIN-4 at even } \\
\text { lower elevation than CIN-3). }\end{array}$ & $\begin{array}{l}\text { Discarding } \\
\text { the results }\end{array}$ \\
\hline $\begin{array}{l}\text { Bimodal distribution } \\
\text { of ages - component } \\
\text { FMM1 is too young }\end{array}$ & $\begin{array}{l}\text { (1b) Lateral sediment } \\
\text { reworking in Late Glacial, } \\
\text { with part of the reworked } \\
\text { material not bleached }\end{array}$ & $\begin{array}{c}\text { The ingrown meanders do not show } \\
\text { much reworking or deposition } \\
\text { The Quaternary cover is too thin and } \\
\text { fining upward to indicate floodplain fill } \\
\text { reworking [16] }\end{array}$ & & $\begin{array}{l}\text { Use older } \\
\text { ages in FM } \\
\text { model }\end{array}$ \\
\hline $\begin{array}{l}\text { Bimodal distribution } \\
\text { of ages-the older } \\
\text { ages (FM2 component } \\
\text { in FM model) }\end{array}$ & $\begin{array}{l}\text { (2) Insufficient bleaching } \\
\text { of a fraction of sediments }\end{array}$ & $\begin{array}{l}\text { Surfaces of point bars were sampled, } \\
\text { with a good chance for having been } \\
\text { bleached under low discharges }\end{array}$ & $\begin{array}{l}\text { Too dense suspension in } \\
\text { coarse bedload of event-like } \\
\text { deposition could prevent } \\
\text { bleaching }\end{array}$ & $\begin{array}{l}\text { Use younger } \\
\text { ages in FM } \\
\text { model }\end{array}$ \\
\hline $\begin{array}{l}\text { Reverse order of Late } \\
\text { Glacial ages with } \\
\text { respect to elevation }\end{array}$ & $\begin{array}{l}\text { (3) Late Glacial } \\
\text { non-conformity, i.e., } \\
\text { fluctuating erosion base } \\
\text { (quickly repeating erosion } \\
\text { and deposition) }\end{array}$ & Such mechanism has not been described yet & $\begin{array}{l}\text { The study area has settings } \\
\text { resembling alluvial fan, } \\
\text { where authigenic cycles } \\
\text { (avulsions, reworking) } \\
\text { are common }\end{array}$ & $\begin{array}{l}\text { Further study } \\
\text { is needed }\end{array}$ \\
\hline
\end{tabular}

\subsection{Distribution of Sn-Contamination in Stage 0 Sediments}

Detailed examination of the Sn contamination was conducted in the channel belt 0 upstream of Žatec in the floodplain segments (Figures 1B and 10) by in-situ XRF analysis. The sampling provided insight into the thickness of the total and contaminated sediment strata of the abandoned channel fills or overbank fines, as only such fine sediments were retrieved by the manual grove corer.

In Stroupeček (Figure 10B), meander scars were identified in the DTM and the field, where $70-120 \mathrm{~cm}$ of fine sediments was retrieved. All sites in the depressions showed Sn contamination at depths of at least $70 \mathrm{~cm}$, while the higher bar surfaces (STR-12 and STR-14) were not contaminated, apart from a thin surface layer of flood deposits. At this site, elevated parts of floodplain 0 were thus cut and laterally filled with sediments before the Sn mining peak.

Approximately $100 \mathrm{~cm}$ of fine sediments was retrieved in Stroupeč (Figure 10C), with most profiles strongly contaminated by $S n$ to depths more than $50 \mathrm{~cm}$. Sediments in shallow depressions (meander scars: STR-3 and STR-7) were contaminated to depths of more than $120 \mathrm{~cm}$, i.e., the entire fine stratum. Small loops of meander scars and lack of scroll bars in both Stroupeček and Stroupeč indicate a braided system similar to the Libočany channel represented on historical maps (Figure 5B) rather than active meandering, which would have produced scroll bars or larger circular meander scars with cut-off necks. Their fills in STR-3 and STR-7 were all younger than 16th century.

In Záhoří (Figure 10D), typically only ca. $60 \mathrm{~cm}$ of fine sediments were found, wherein moderate contamination by Sn occurs in the top $\sim 40 \mathrm{~cm}$. Several profiles, such as ZAH-4, ZAH-5, and ZAH-12, were contaminated by Sn at depths greater than $90 \mathrm{~cm}$, indicating a channel that was abandoned during the Sn mining peak or soon afterwards. Only one core (ZAH-11) showed nearly no Sn contamination, which clearly represented a remnant of an older surface, similar to that at higher levels in the 0 channel belt in the Stroupeček site.

In Libočany, the channel belt around the multi-channel system depicted in the digital elevation model and on historical SK maps (Figures 4 and 5B) was strongly contaminated by Sn. Floodplain topography resembled that in the left bank sites (Stroupeček, Stroupeč, and Záhoří) depressions remained after the former low-sinuous channels with large bars in the channel. The distribution of Sn contamination showed lateral channel shifts that started before the mining peak and continued during that peak. The same pattern was found in the lower reach of the Ohře River in the Písty area [16]. In the Písty area, remarkable scroll bar structures documented the enhanced lateral floodplain reworking, which started just 
before the mining peak and continued during or soon after this peak, as evaluated by the Sn contamination pattern [16].
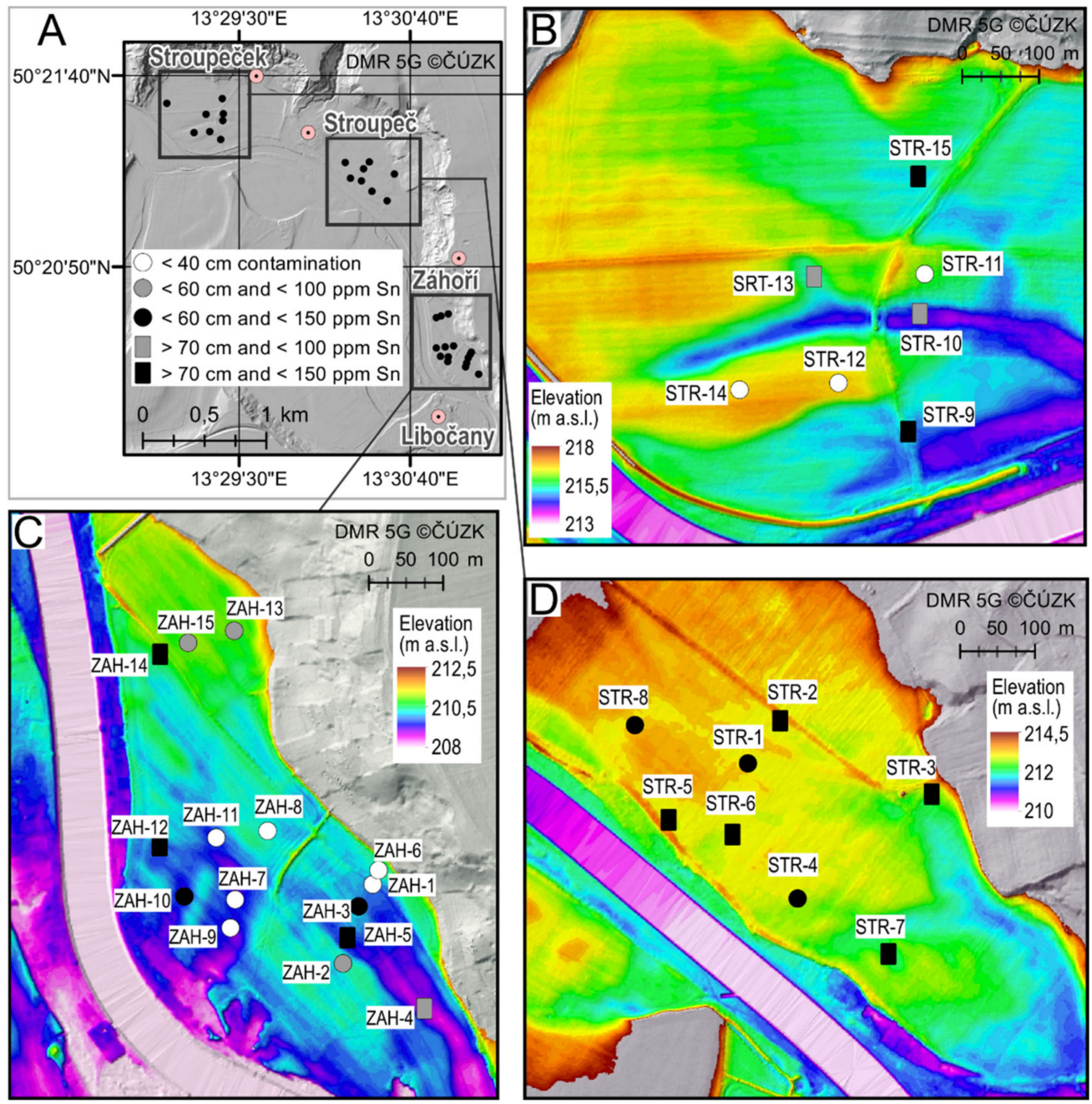

Figure 10. Recent channel belts (stage 0) upstream Žatec were sampled extensively (A). Detailed DTM and Sn contamination in Stroupeček (B), Stroupeč (C), and Záhoří (D). Position of areas in panels $\mathrm{B}$ to $\mathrm{D}$ is indicated by black rectangles in Figure 1B.

In valley floor below the site Horkau, located in the $0 \mathrm{~b}$ channel belt upstream of Libočany and on the right side of channel belt 0 opposite to Stroupeč (Figure 1B), showed only a thin layer of floodplain fines (a few $\mathrm{dm}$ ) over a cobbly and pebbly channel bottom deposits, while all the fine deposits were contaminated by Sn. This observation documents the limited deposition (or subsequent erosion) of finer sediments in the low levels of the $0 \mathrm{~b}$ channel belt.

\section{Discussion}

\subsection{Channel Pattern of the Ohře River Since the Late Pleistocene}

The geomorphic evaluation (Table 1) and OSL ages (Tables 2 and 3) show that the Ohře River had meandering pattern during the LGM, $\mathrm{P} / \mathrm{H}$ transition, and a major part of the Holocene. The palaeomeanders from the LGM and P/H transition (stage II-III) were large, similarly to some other European rivers over the time periods [54-56]. However, the channel-forming discharges of the LGM rivers were likely achieved only for a few days or weeks of ice or snow melting in their catchments [57]. Later, during the Holocene, the channels of the Ohře River (stages I and 0) became much narrower (40-90 m) than those of the large P/H meanders (stage II, 130-200 m, Table 1), and the mean radii decreased 
substantially ( $>500 \mathrm{~m}$ in stage II and $250 \mathrm{M}$ in stage I, Table 1 ). These trends have been found universally in European rivers around the $\mathrm{P} / \mathrm{H}$ transition $[54,55,58]$. Thus, during the Middle and Late Holocene the discharge of the river dropped (stage I), though it reached the smallest values during historical times (stage 0). Finally, in historical times the sinuosity of the channel dropped, and it incised into the valley floor. This incision was completed by river engineering in the 20th century. Before the 20th century multiple channel sections developed, however as the result of engineering works the active channel became simple with low-sinuosity.

\subsection{Incision of the Ohř River Since the Late Pleistocene}

Two main types of fluvial surfaces were identified in the area. On higher elevations, along the rims of the valley patches of flat surfaces remained (stage III). For these surfaces the typical terrace development scheme could be applied [12,13,24-27]: they were formed by fluvial aggradation during an aggradational terrace development stage, and they bear some remnant of large palaeomeanders. However, younger surfaces (stage I-II) are related to incised meanders: their meander cores reflect the elevation of that flat surface, which existed before the slow incision of the river, while the related palaeomeanders reflect the termination of a given incision phase.

The incision phase in the Ohře River valley occurred between the end of the LGM and the Early Holocene (i.e., around the $\mathrm{P} / \mathrm{H}$ transition). The OSL data from various palaeomeanders reflect, that erosion was a dominant process during the entire studied period, only very short (yet undated) aggradational periods could appear. Panin et al. [59] dated the last major incision phase in the Seym (Seim) River (Ukraine/Russian transboundary river) to a period between the LGM and the beginning of the Holocene and supported their findings with reports on other European rivers; the overview of the central European rivers $[60,61]$ confirms that model. Kasse et al. [55] concluded that the major incision phase of the Roer River occurred between the Younger Dryas and the Early Holocene. The ingrown (incising) character of the LGM meanders of the Ohře River is obvious from the declining surfaces of meander cores (Figures 4 and 6), and can be found in all big palaeomeanders of stage II or the remnants of their cores in stage III, particularly in Číňov, Nové Sedlo II, Rybňany-Zálužice, and Hradiště-Strkovice. Occasionally, only the erosion remnants of meander cores have been preserved, while their lowest channel fills were eroded (Zlatník Hill, Figure 4; Rybňany-Zálužice palaeomeander, Figure 6).

The considerable Holocene incision and formation of a novel valley floor is indirectly supported by the distribution of bones and teeth of large Pleistocene mammals, such as rhinoceros and mammoths, attributed to the Palaeolithic hunters. They were found mainly on edges of the gravel terraces south of Žatec [35], i.e., terraces IV or higher based on notation by Elznicová et al. [16]. These levels are much higher than those addressed in this paper. One notable exception was a single locality above the former Dreher brewery ([35], pp. 113 and 114), just above the former entry to the Žatec palaeomeander. This locality has an elevation between 200 and $210 \mathrm{~m}$ a.s.l. (i.e., between levels I and II), and is thus assigned to the $\mathrm{P} / \mathrm{H}$ transition (Figure $2 \mathrm{~B}$ ).

The developed surfaces could be considered as strath terraces, as the river incised into much older valley-floor deposits. The bedrock of the well-preserved ingrown meanders of the Ohře River are very cohesive Miocene sediments, mainly clays and coaly clays. The mechanical resistance of these rocks made the outer slopes of the meander steep and smooth (Figure 11F). The meander cores are covered by cobbly, gravelly, and sandy lateral deposits with a typical thickness of ca. 3-4 m according to the CGS database of drill cores [16]. The Pleistocene sediment layers are therefore thinner than the entire elevation difference of the declining surface of the meander cores (5-10 m, Figure 5). In particular, the stage II palaeomeanders of the Ohře River are genetically closer to the strath terraces than to cut-and-fill terraces, the latter being easier to date due to a larger amount of deposits and their protection to aggradation. 

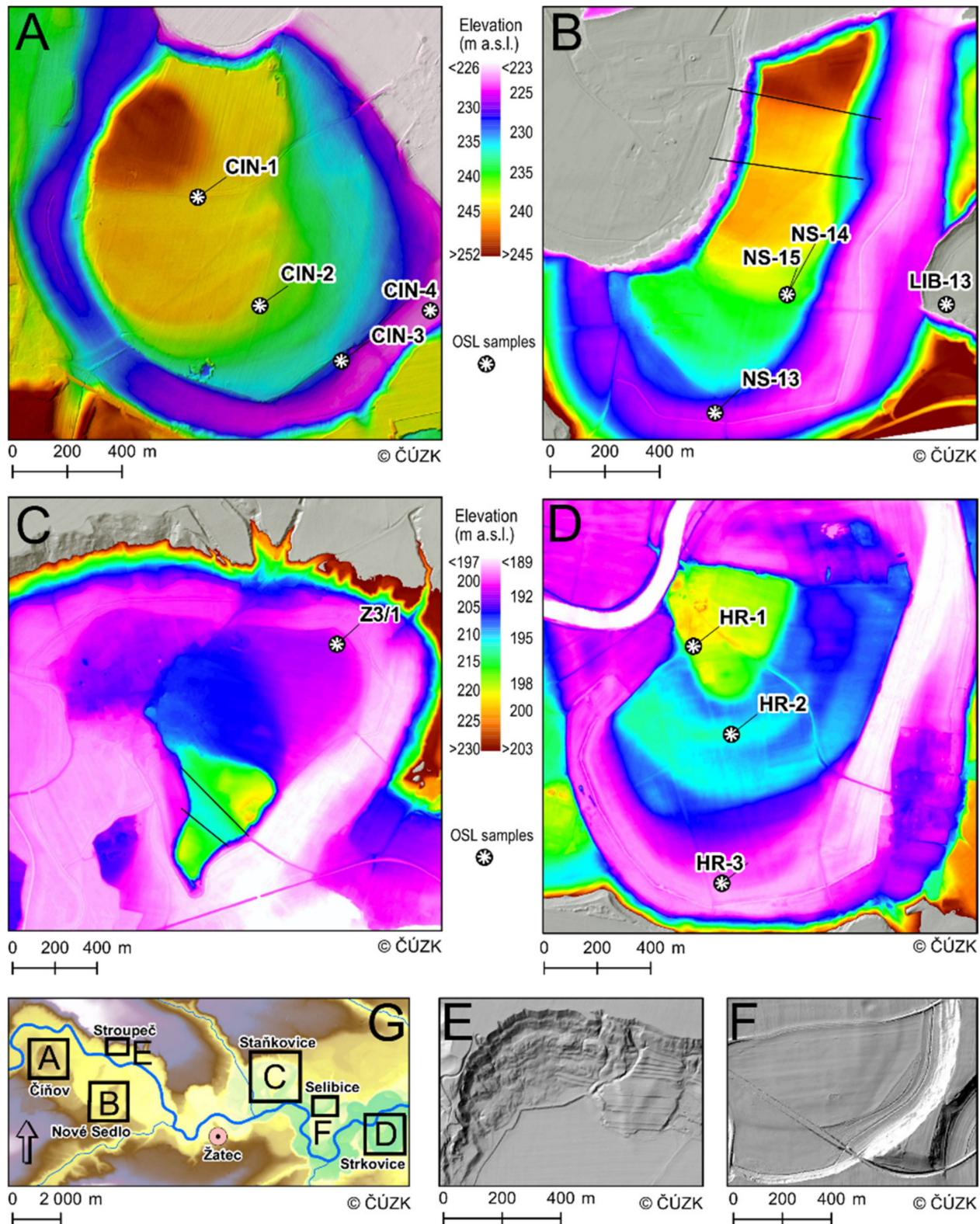

Figure 11. Detailed DTM of meander cores (A-D) and meander edges (E,F). Bellow the top of large meander cores in Číňov (A), Nové Sedlo (B) and Staňkovice (C) the low-sinuosity palaeochannel scars are found (indicated by straight lines in (B) and (C)). Staňkovice $(\mathbf{C})$ and Hradiště-Strkovice meander cores (D) have nearly triangular shape rather than expected circular meander core. Edges of palaeomeanders cut into Oligocene to Miocene loose sandy sediments in Stroupeček are irregular (E), while in Selibice they are smooth (F) as the result of more cohesive Miocene clayey strata. Position of areas A-F are shown in inset $(\mathrm{G})$.

The event-driven large-scale reworking of sediments is typical for alluvial fans [54]. The settings of the Žatec area seem favorable for the formation of an aggradational body, as the V-shaped valley of the narrow gorge at Libočany controls the slope and sedimentation, and the propagation of fluvial processes especially during extreme floods. Upstream of the study area (upstream Kadaň, Figure 1A) the high slope and V-shaped river valley provided a limited accommodation space for sediments $[15,32,33]$, in contrary downstream of the "bottleneck" the decreased slope conditions had favoured sediment deposition. Therefore, the Žatec area represents the sediment accommodation zone immediately downstream of the sediment transfer zone. The Libočany gorge was probably even relatively narrower to the upstream valley segment during the formation of large palaeomeanders of development 
stage II. Assuming that the palaeomeanders II preserved on the right side of the valley (Č́ńnov and Nové Sedlo) formerly had their symmetric counterparts on the left side of the valley that are currently missing, the valley width was ca. $2000 \mathrm{~m}$ upstream of Libočany and only $700 \mathrm{~m}$ in the Libočany gorge, with the former valley width being estimated from the current topography at a $30 \mathrm{~m}$ elevation above the lowest level 0 . The existence of the Libočany gorge could have resulted from the mouth of a side valley of the Liboc Creek, which springs in the Doupov Mountains. The inputs from side valleys can contribute to the sediment plug formation in the Ohře River channel [32]. This effect could have favoured Late Glacial sediment deposition upstream Žatec.

Loess deposition could also partake in the late glacial development, as has been shown for other European river valleys during the Late Glacial [55,59,62]. Loess deposits were found in higher terraces of the Ohře River ([20], CGS maps) and probably in levelled surfaces of stage III and higher, where meander scars are sparsely visible [16]. Sediment accumulation in the Late Glacial followed by erosion and channel incision before the $\mathrm{P} / \mathrm{H}$ transition and Holocene was a phenomenon typical of periglacial rivers $[22,55,57,61]$ and presumably also for other rivers globally (e.g. Portugal, [63], Australia, [64]). The expected presence of voluminous sediment bodies in the Žatec area could depict periods of repetitive lateral and vertical deposition and reworking in scenario 3.

\subsection{Peculiarities of the Ingrown Meanders in Terrace Development}

In the study area the remnants of meander cores (Figure 11A,B) are common, they belong to the development stages I and II. They could be identified as 'floodplain islands' [50], 'hillocks' [65], or 'cliffs' in the Ohře River floodplain, which are elongated or nearly polygonal elevations with gently descending surfaces, scattered on the present valley floor, such as Zlatník hill (Figures 4 and 12). These 'cliffs' can be remnants of meander cores created by neck-cutoffs, the shape of which can be inferred by extrapolating the 'cliffs' to opposite sides of the valley. An example of such an extrapolation is shown in Figure 13; the hypothetic meander neck shown here would explain the existence of transverse meanders of Nové Sedlo I and Alte Eger (Figure 4). Its cut-off would rationalise the incision of the channel belt stage 0 north of Nové Sedlo.

The meander cores usually have gentle slopes towards their palaeomeander scars, but their distal sides could be heavily eroded by subsequent lateral erosion (Figure 11C). These features were formed in the material of an older valley floor. Although the oldest incised meanders belong to stage II, their meander cores were probably developed in the alluvium of level III, deposited by the Late Pleistocene meandering Ohře River or in the alluvium of an older, probably braided river. Our hypothesis on braided pattern is based on common fragments of low-sinuosity and relatively narrow palaeomeander scars on tops of meander cores (indicated by straight black lines in Figure 11B,C). Braided channel pattern was more frequently reported in European rivers around the LGM, compared to meandering [23,58-60], thus, we hypothesise that the Late Glacial meandering of the Ohře River started on the braided plain and was associated with incision, as proposed by the general model from Vandenberghe [23].

\subsection{Peculiarities of the Holocene Evolution of the Ohře River Valley}

The Holocene channels laterally reworked some of the palaeomeander scars, such as in the Hradiště-Strkovice meander, of which core was shaped during the LGM (HR-1 and HR-2, Table 1). However, its lowermost point bar and meander scar were filled during the last millennium (HR-3, Table 3), when it was finally abandoned by the formation of the current channel belt 0 . The scars subsequent to the narrower wandering channels of the middle and late Holocene can be distinguished at the bottom of the last palaeochannels of development stage II (Figure 11B-D). 


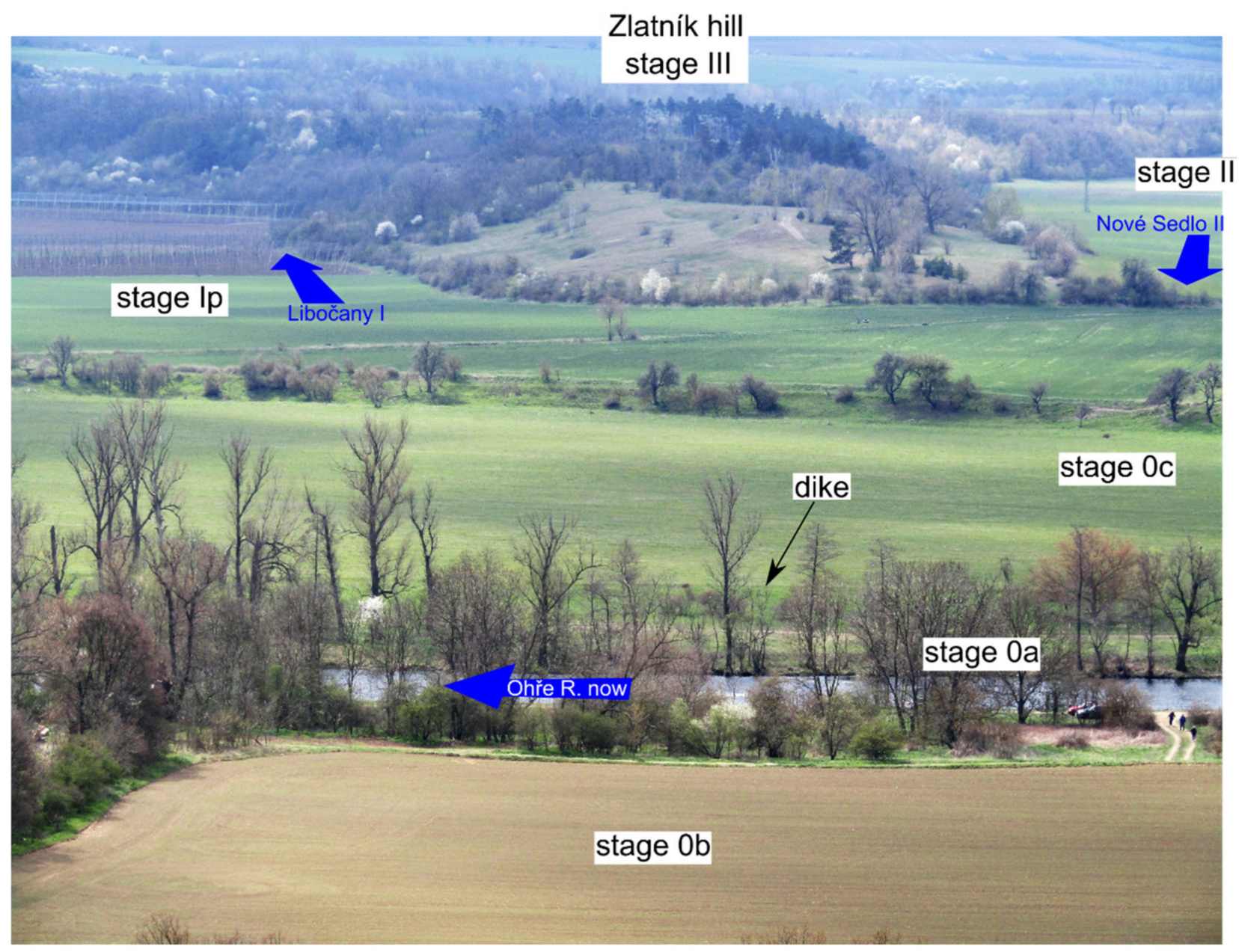

Figure 12. Zlatník hill as an example of erosional remnants of Late Glacial meander cores in the Holocene floodplain. In front Stroupeček site 0b. Blue arrows show directions of past and current river flows around the hill and underline the importance of the hill persistence in the valley floor. Photo was taken from the uppermost edge of the Ohře River valley $80 \mathrm{~m}$ above the current Ohře River channel.

Level Ip upstream of Žatec hosts numerous scars after abandonment of river channels (Figure 4) with no visible traces of active meandering, such as scroll bars or oxbow lakes after the meander neck breakthrough and cut off. The Holocene channels upstream of Žatec, for example, Alte Eger, is a loop elongated nearly perpendicularly to the valley axis (transverse meanders or loops). Transverse meanders typically occur for rivers incised in rocks that are too resistant with respect to the actual channel forming discharge. Thus, softer material in lithological heterogeneities or faults in resistant rocks is preferentially eroded, while the meander neck cut-offs are exceptional [6]. In the case of the Ohře River, the Miocene clays and coaly clays in the Late Glacial meander cores represented highly resistant rocks, while the Holocene fluvial sediments in the meander scars represented the softer material that was easier eroded or laterally reworked. Sandy Oligocene to Miocene deposits were also much less cohesive. They occasionally outcrop in the left (northern) slope of the river valley (Stroupeček and surroundings). Meanders with irregular slopes and gully erosion features and landslides in the meander edges (DTM in Figure 11E) were cut into Miocene sandy clays and sands according to the CGS maps. It suggests, that bedrock heterogeneities affected the fluvial development of the Ohře River in the study area during the Holocene, similar to the models discussed by Malatesta et al. [13].

The elevation profiles (Figures 3 and 6) show that the Holocene development, particularly upstream of Žatec, was controlled mainly by the occasional abandonment of transverse channels of stage I by breaking through the remnants of the cores of the $\mathrm{P} / \mathrm{H}$ 
meanders (stage II). These breakthroughs resulted in the formation of the incised belt around the current low-sinuosity channel of stage $0 \mathrm{a}$, with the channel slope increasing due to the natural channel shortening (Figure 2C). Similar mechanisms (channel avulsion and shortening) resulted in a channel belt incision of the Vistula River in the area studied by Dobrzańska and Kalicki [58].

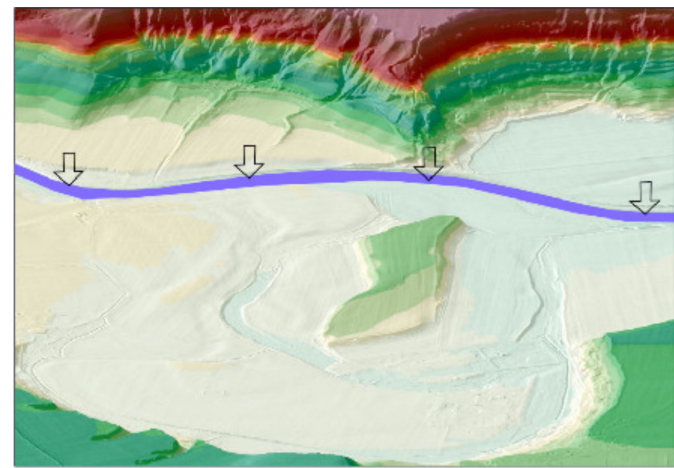

Present time - stage 0a

Continuing lateral erosion of meander necks

Narrow channel belt, anthropogenic incision



Late Holocene - stage $0 \mathrm{~b}$

Continuing lateral erosion of meander necks Abandonement of transverse meanders by breaking through the last meander cores Low sinuosity channel in narrow belt

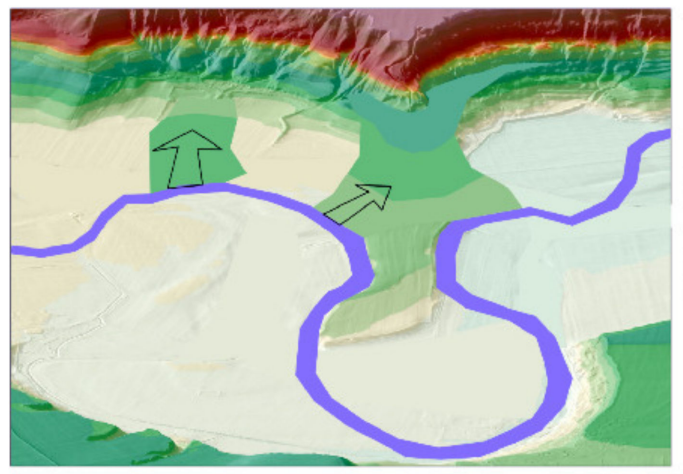

Early and Mlddle Holocene - stage I Lateral erosion of large meander necks Floodplain planation by lateral reworking Transverse meanders

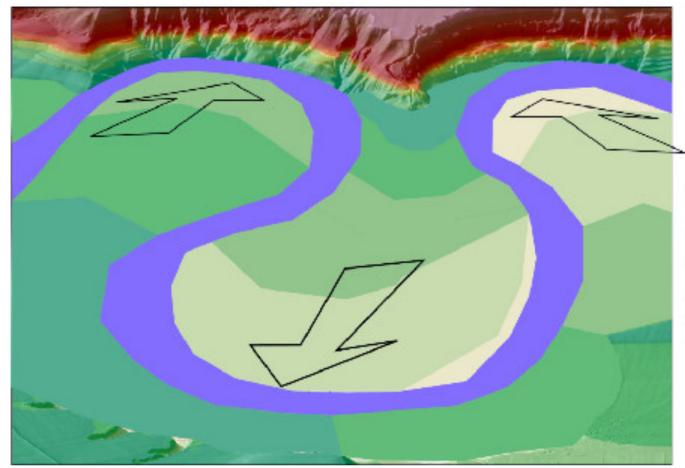

Late Glacial and P/H transition - stage II Large incising meanders shaping valley floor Large channel forming discharge Erosion of cohesive Neogene sediments

Figure 13. Hypothetical evolution of the Late Glacial meander north of Nové Sedlo. Late Glacial meander core could act as obstacle of the Early and Middle Holocene flow of the Ohře River and cause formation of transverse meander loops Nové Sedlo I and Alte Eger (Figure 4). 
It is tempting to attribute the cut-offs of the $\mathrm{P} / \mathrm{H}$ incised meander necks to the Late Holocene climatic extremes, as the average channel forming discharges in the Holocene were considerably smaller than those around the $\mathrm{P} / \mathrm{H}$ transition and usual Holocene discharges were too low to shape the valley floor. Thus, the Holocene discharges were insufficient to 'finish' the $\mathrm{P} / \mathrm{H}$ meander cut-offs. The major climatic extremes of the last millennium were definitely the three extreme periods of the Little Ice Age (LIA). The general challenge is in dating these assumed incision events as they mainly caused erosion. Alte Eger is a candidate for the youngest abandoned palaeochannel upstream of Žatec, because it is still not completely filled with sediments yet and the channel has even obtained its historical name. The Sn contamination of the channel fill (Břežany-1, Břežany-2) and the proximal floodplain (NS-16) shows that Alte Eger was probably abandoned during the mining peak in the 16th century, or not long before that peak. The abandonment occurred even before finishing the incision of the channel belt 0 down to the present-day level, as the contaminated sediment would not have been deposited in the Ip floodplain level. The OSL datum of the point bar of Alte Eger (NS-16, Table 3) confirms that channel developed in the 1st millennium AD.

The Hradiště-Strkovice meander (Figure 11D) was perhaps the youngest abandoned one downstream of Žatec, as inferred from the OSL age of HR-3 (Table 3) and thick Sn contamination in the meander scar [16]. The temporal coincidence of the abandonment of the Alte Eger arm and Sn mining peak would explain the nearly simultaneous changes in the $\mathrm{Sn}$ concentration and $\mathrm{K} / \mathrm{Rb}$ ratio. The $\mathrm{K} / \mathrm{Rb}$ change could be attributed to the input of large volumes of Miocene sediments from the hypothetical remnant of the Late Glacial meander neck (Figure 13) to the Ohře River system. Then the Sn contamination and $\mathrm{K} / \mathrm{Rb}$ changes could be temporally close but independent processes, which would explain the minority group of sediments in Figure 8B.

In a recent study [16], we found two remarkable palaeomeanders with clearly visible scroll bars in the Písty site $60 \mathrm{~km}$ downstream of Žatec, developed and abandoned in the time period shortly preceding or coeval with the Sn mining peak. These processes followed a period of stable floodplain before ca. 2 ka [16]. Similarly, as in the Žatec area, after the abandonment of these palaeomeanders in Písty, the river channel stopped meandering and turned into a low-sinuous narrow channel belt.

The latest identified steps of cut-offs/channel belt incisions in the Žatec area, Alte Eger, Hradiště-Strkovice palaeomeander, and the two scroll bar systems in the Písty area in the lower river reach [16] could thus have occurred in the first or second period of the LIA, i.e., in the middle of 15th or 17th centuries. The last reorganisation of the Morava River channel system (eastern Czech Republic) in the Strážnice area was also attributed to the LIA [11]. The possible relationship between the elevated flood activities and LIA has been discussed by several researchers in other European [9,66] or US temperate rivers [67]. The Weiße Elster River flows from the Fichtel Mountains to the west of the Krušné Hory Mountains; that river eroded loams and replaced them by gravelly sediments during the LIA ( $\mathrm{H}$. Von Suchodoletz, Dresden University, personal communication). The particular impact of LIA on European rivers should be addressed in further case studies, where the climatic effect can be blurred or interrelated with the changing human impact in river catchments. The general problem of distinguishing human and climatic forcing in fluvial systems stems here from co-incidence of the end of Middle Ages, which opened new technological perspectives also in ore mining and metallurgy, and beginning of LIA, that both could affect budget of fluvially transported solids.

\subsection{The Anthropogenic Impact on the Ohře River Valley}

The Ohře River development in the middle and late Holocene produced relatively flat, low gradient surfaces (Ip and Im) in the Ohře River floodplain, which hosted laterally shifting or meandering channels, with active meandering being limited to some areas downstream of Žatec. Further incision of these Holocene channels occurred by the occasional breaks through the meander core remnants. The term "break through" here stand 
for avulsion into meander neck to distinguish it from meander cut off by laterally shifting channel of actively meandering river. The Holocene narrow, low-sinuous channels of stage I (Nové Sedlo I, Alte Eger, Libočany I, Figure 4) have thus been abandoned in a stepwise manner by ongoing channel shortening and weak incision (Figure 2B). According to the CGS core database, the current valley floor is covered by a 3-4 $\mathrm{m}$ channel and overbank sediments on the Oligocene to Miocene bedrock [16]. Human action could contribute to this natural process (channel shortening and weak incision) by artificial meander cut-offs, one of which was documented in the Žatec city chronicle [68], and by the construction of levees (DTM, Figure 5), weirs, and revetments that limit lateral channel erosion.

The most recent channel shortening in the Žatec area occurred between the time of drawing of the SK maps (the 1840s) and the present (Figure 5). In 1960s and 1970s, the Kadan̆ and Nechranice Reservoirs (Figure 1A) were established, which trap most particulates transported formerly from the middle reach of the Ohře River [33,69]. River damming has resulted in 'hungry waters' and downstream vertical channel erosion [51], which are in conjunction with the natural long-term incision of the Ohře River channel belt. The Ohře River has thus followed general incision trends, typical for many European rivers: loss of connectivity of the river channel and floodplain [70]. Presumably, both natural and long-term Holocene trajectories together with the engineering measures (Figure 5) could have caused a lack of alluviation and vertical aggradation in the Ohře River valley floor, prevented the current formation of natural levees and deposition of fine silty overbank sediments, irrespective of a strong human impact in the river catchment.

\subsection{Methodological Notes}

The OSL ages of the surfaces of the big Ohře palaeomeanders are not always ordered according to the elevation of the sampled strata relative to the level of stage 0a. Some samples (Figures 4 and 6) show reverse orders. For example, the younger ST-1 was found at higher elevations than the older HR-2. Other samples seem too young, such as those from the slope of the Činnov meander core (CIN-2 and CIN-3), or too old with respect to their positions relative to the recent channel belt (HR-2 and RY-3). We also found non-monomodal distribution of ages in the OSL results (Table 3, samples RY-1 and RY-3).

The elevation-age misfits can be interpreted by the scenarios presented in Table 4 . Among them, particular attention should be given to scenario 3, wherein repetitive erosion and accumulation of sediments occur in stage II during the LGM, and between the LGM and $\mathrm{P} / \mathrm{H}$ transition, i.e., erosion/deposition/remodelling of the meander cores. The current surface of the floodplain in scenario 3 would be an envelope of a time-series of erosion bases of several $\mathrm{P} / \mathrm{H}$ channels, with the vast majority of temporarily deposited sediments eroded before the ultimate abandonment of the last channels of such large meanders. This envelope would show (in current topography) the deepest local erosion of the cohesive Miocene bedrock (covered by the Quaternary channel armour) rather than the unidirectional downslope formation of scroll bars. Previous studies have attributed distinct parts (elevation intervals) of the slopes of these meander cores to distinct glacial/stadial periods $[19,20]$. We assigned these distinct elevation intervals to a set of erosion bases representing a much shorter time interval during the Late Glacial. This is presumably attributable to the environmental disruptions between the LGM (ca. 22-18 ka) and the Holocene, such as the Bølling-Allerød interstadial and Younger Drays stadial.

\subsection{Outlines of Future Research}

The OSL dating of the Ohře River sediments provided a new perspective for fluvial research in this valley as older local studies require complete revision. Detailed insight showed that the $\mathrm{P} / \mathrm{H}$ incision was not a unidirectional vertical process, resulting in plain strath terraces with one step per a glacial cycle. The meanders, formerly declared to be of the Pleistocene age and assigned so in the Czech geological maps, although no direct sediment dating has yet been available for them), were formed and abandoned during the Late Glacial and Holocene, as stated by Elznicová et al. [16] and confirmed and extended 
in this work. Natural processes caused channel shortening by very slow breakthroughs through the $\mathrm{P} / \mathrm{H}$ meander cores during the Holocene, postponed process initiated during the LGM and P/H transition (Figure 13). Some terrace levels of the Ohře River have not been formed as a direct consequence of major climate change, but presumably due to the lateral channel movement combined with persistent [12] and stepwise incisions of the channel belt, caused by its shrinking on advancing the vertical incision [13]. The extensive floodplain sediment reworking could have produced fragments of elevated palaeosurfaces that agree with models of the mosaic structure of floodplains due to the spatially diverse probability of sediment reworking by meandering rivers [11]. The realistic results available for the Ohře River can be rationalised in two ways: either by a systematic general incision trend, expressed as a straight line in elevation vs. age (line in Figure 7), or event driven incision, where the major abrupt events were the LGM and $\mathrm{P} / \mathrm{H}$ transition, and the late Holocene abandonment of the meandering pattern (grey rectangles in Figure 7). The decision as to which of these models is more realistic would require further sediment sampling and dating or process modelling.

We hypothesise that the Holocene climatic extremes could be responsible for the most recent cut-offs of the Late Glacial meanders, in particular Nove Sedlo I and Alte Eger, Staňkovice, Stekník, and Hradiště-Strkovice palaeomeanders. In particular, the general incision trend in Figure 7 is only a general tendency, and is an envelope of the past events in reality, as discussed above. The pattern of Sn contamination indicates the last temporal cumulation of the meander cut-offs in the case of Alte Eger and HradištěStrkovice; the corresponding channel belt incision occurred during the LIA. Detailed work is required to improve the age constraints of these episodes to evaluate the hypothetic event-driven model for the Ohře River valley development. If proven, the Ohře River will require an interpretation that is substantially different from that of the PDF discussed in the Introduction. The case study in the Ohře River documents inherent complexity of the fluvial system, that prevented simple strath terrace formation during the global environmental change $(\mathrm{P} / \mathrm{H}$ transition) and resulted in the $\mathrm{P} / \mathrm{H}$ incision fragmented to the entire Holocene by inherited LGM topography, heterogeneous bedrock geology, and decreased channel forming discharge. These individual factors should all be considered in data interpretation, rather than attempting to "automatically" summarise available data in the PDF.

The results presented above could impact the decision making for the future restoration of the Ohře River. Brown et al. [17] declared a need to understand the river behaviour before restoration activities. For European rivers, Brown et al. [17] considered the trajectory from sediment-starving swampy floodplains with laterally stable river channels during the early to middle Holocene to clastic floodplains aggraded by anthropogenic siltation and channel meandering during the late Holocene as valid. The Ohře River has followed an opposite scenario, with persistent Holocene incision and change in the naturally meandering river to a narrow, incised channel belt, with a lack of siltation despite mining activities, large-scale deforestation in montane parts of the catchment, and intensive agriculture in the entire catchment. The Ohře River development underpins the idea by Cordier et al. [1] which states that understanding the current river behaviour, its trajectory must be followed not only for a few centuries, but for the entire Holocene and beyond. If the river restoration practices in Europe would mean the renewal of connectivity between the floodplains and channels, as discussed by Maaß and Schüttrumpf [69], this goal would contradict to the general Holocene evolution in the Ohře River.

\section{Conclusions}

The palaeomeanders in the Ohře River valley are much younger than previously expected and actually presented in the maps of the Czech Geological Survey that prompts for revisiting preceding fluvial geomorphic studies not based on state-of-the-art knowledge and instrumental dating. The palaeomeanders document dynamic and spatially heterogenous development of the river valley between the Last Glacial Maximum and Holocene. 
The lack of anthropogenic aggradation in the Ohře River floodplain is caused by persistent river incisions that occurred since the Last Glacial Maximum or the Pleistocene/Holocene transition. The termination of this incision was postponed to the present time by the decrease in channel-forming discharges during the early Holocene. The incision was slowed down by much lower erosive power of the Holocene river compared to the Late Glacial; the last steps of that were postponed to the Mediaeval and modern periods, when the channel belt shrunk to its narrowest mode in the last $30 \mathrm{ka}$ and the river has stopped active meandering, presumably due to the co-incident natural forcing and perhaps also anthropogenic impacts. The Holocene evolution of the Ohře River valley floor consisted of a series of incision events, which were supposedly triggered by climatic extremes and reflected inherited Late Glacial morphology and bedrock heterogeneity. The valley floor development was far from simple models of geomorphic record of the climate changes.

Author Contributions: Conceptualization, T.M.G.; Funding acquisition, J.E.; Investigation, J.E. and T.K.; Methodology, G.S.; Supervision, T.K.; Writing—review \& editing, T.M.G. All authors have read and agreed to the published version of the manuscript.

Funding: The research was funded by J. E. Purkyně University in Ústí nad Labem via institutional grant agency, project number UJEP-IGA-TC-2019-44-02-2.

Institutional Review Board Statement: Not applicable.

Informed Consent Statement: Not applicable.

Data Availability Statement: The data presented in this study are available in Table 3.

Acknowledgments: The authors thank to M. Hošek, M. Faměra (both Institute of Inorganic Chemistry CAS), J. Elznic, and F. Elznic, who assisted in some fieldworks. Laboratory sample processing and XRF analyses were performed by P. Vorm and M. Maříková (Institute of Inorganic Chemistry CAS).

Conflicts of Interest: The authors declare no conflict of interest.

\section{References}

1. Cordier, S.; Briant, B.; Bridgland, D.; Herget, J.; Maddy, D.; Mather, A.; Vandenberghe, J. The Fluvial Archives Group: 20 years of research connecting fluvial geomorphology and palaeoenvironments. Quat. Sci. Rev. 2017, 166, 1-9. [CrossRef]

2. Macklin, M.G.; Benito, G.; Gregory, K.J.; Johnstone, E.; Lewin, J.; Michczynska, D.J.; Soja, R.; Starkel, L.; Thomdycraft, V.R. Past hydrological events reflected in the Holocene fluvial record of Europe. Catena 2006, 66, 145-154. [CrossRef]

3. Chiverell, R.C.; Thorndycraft, V.R.; Hoffmann, T.O. Cumulative probability functions and their role in evaluating the chronology of geomorphological events during the Holocene. J. Quat. Sci. 2011, 26, 76-85. [CrossRef]

4. Oldknow, C.J.; Hooke, J.M. Alluvial terrace development and changing landscape connectivity in the Great Karoo, South Africa. Insights from the Wilgerbosch River catchment, Sneeuberg. Geomorphology 2017, 288, 12-38. [CrossRef]

5. Faust, D.; Wolf, D. Interpreting drivers of change in fluvial archives of the Western Mediterranean-A critical view. Earth Sci. Rev. 2017, 174, 53-83. [CrossRef]

6. Petit, F.; Hallot, E.; Houbrechts, G. The Semois Valley in Southern Ardenne: Short-Wavelength, Large-Amplitude Meanders Incised into a Slaty Basement. In Landscapes and Landforms of Belgium and Luxembourg; Demoulin, A., Ed.; Springer: Berlin/Heidelberg, Germany, 2018. [CrossRef]

7. Rodriguez-Lloveras, X.; Machado, M.J.; Sanchez-Moya, Y.; Calle, M.; Medialdea, A.; Sopeña, A.; Benito, G. Impacts of sediment connectivity on Holocene alluvial records across a Mediterranean basin (Guadalentín River, SE-Spain). Catena 2020, 187, 104321. [CrossRef]

8. Notebaert, B.; Broothaerts, N.; Verstraeten, G. Evidence of anthropogenic tipping points in fluvial dynamics in Europe. Glob. Planet. Chang. 2018, 164, 27-38. [CrossRef]

9. Petř́k, J.; Petr, L.; Adameková, K.; Prišt'áková, M.; Potůčková, A.; Lend’áková, Z.; Frączek, M.; Dresler, P.; Macháček, J.; Kalicki, T.; et al. Disruption in an alluvial landscape: Settlement and environment dynamics on the alluvium of the river Dyje at the Pohansko archaeological site. Quat. Intern. 2019, 511, 124-139. [CrossRef]

10. Matys Grygar, T.; Nováková, T.; Mihaljevič, M.; Strnad, L.; Světlík, I.; Koptíková, L.; Lisá, L.; Brázdil, R.; Máčka, Z.; Stachoň, Z.; et al. Surprisingly small increase of the sedimentation rate in the floodplain of Morava River in the Strážnice area, Czech Republic, in the last 1300 years. Catena 2011, 86, 192-207. [CrossRef]

11. Bradley, D.N.; Tucker, G.E. The storage time, age, and erosion hazard of laterally accreted sediment on the floodplain of a simulated meandering river. J. Geophys. Res. Earth Surf. 2013, 118, 1308-1319. [CrossRef] 
12. Limaye, A.B.S.; Lamb, M.P. Numerical model predictions of autogenic fluvial terraces and comparison to climate change expectations. J. Geophys. Res. Earth Surf. 2016, 121, 512-544. [CrossRef]

13. Malatesta, L.C.; Prancevic, J.P.; Avouac, J.-P. Autogenic entrenchment patterns and terraces due to coupling with lateral erosion in incising alluvial channels. J. Geophys. Res. Earth Surf. 2017, 122, 335-355. [CrossRef]

14. Tofelde, S.; Savi, S.; Wickert, A.D.; Bufe, A.; Schildgen, T.F. Alluvial channel response to environmental perturbations: Fill-terrace formation and sediment-signal disruption. Earth Surf. Dynam. 2019, 7, 609-631. [CrossRef]

15. Matys Grygar, T.; Elznicová, J.; Kiss, T.; Smith, H.G. Using sedimentary archives to reconstruct pollution history and sediment provenance: The Ohře River, Czech Republic. Catena 2016, 144, 109-129. [CrossRef]

16. Elznicová, J.; Kiss, T.; Sipos, G.; Faměra, M.; Štojdl, J.; Váchová, V.; Matys Grygar, T. A central European alluvial river under anthropogenic pressure: The Ohře River, Czechia. Catena 2021, 201, 105218. [CrossRef]

17. Brown, A.G.; Lespez, L.; Sear, D.A.; Macaire, J.-J.; Houben, P.; Klimek, K.; Brazier, R.E.; Van Oost, K.; Pears, B. Natural vs anthropogenic streams in Europe: History, ecology and implications for restoration, river-rewilding and riverine ecosystem services. Earth Sci. Rev. 2018, 180, 185-205. [CrossRef]

18. Engelmann, R. Die Entstehung des Egertales. In Abhandlungen der Geographischen Gesellschaft in Wien; Geographische Gesellschaft in Wien: Wien, Austria, 1922; Volume 12, pp. 1-80.

19. Balatka, B.; Červinka, P. Geomorfologická analýza a vývoj údolních meandrů Ohře v mostecké pánvi (Geomorphological analysis and development of Ohře River valley meanders in the Mostecká pánev (Basin)). Sborník České Geogr. Společnosti 1994, 99, 234-247, ISSN 0231-5300.

20. Tyráček, J. Stratigraphy of the Ohre River terraces in the Most Basin. Sborník Geol. Věd Antropozoikum 1995, 22, 141-157, ISBN 80-7075-184-3.

21. Tyráček, J. Upper Cenozoic fluvial history in the Bohemian Massif. Quat. Intern. 2001, 79, 37-53. [CrossRef]

22. Starkel, L.; Gębica, P.; Superson, J. Last Glacial-Interglacial cycle in the evolution of river valleys in southern and central Poland. Quat. Sci. Rev. 2007, 26, 2924-2936. [CrossRef]

23. Vandenberghe, J. River terraces as a response to climatic forcing: Formation processes, sedimentary characteristics and sites for human occupation. Quat. Intern. 2015, 370, 3-11. [CrossRef]

24. Winsemann, J.; Lang, J.; Roskosch, J.; Polom, U.; Böhner, U.; Brandes, C.; Glotzbach, C.; Frechen, M. Terrace styles and timing of terrace formation in the Weser and Leine valleys, northern Germany: Response of a fluvial system to climate change and glaciation. Quat. Sci. Rev. 2015, 123, 31-57. [CrossRef]

25. Zieliński, T.; Terpiłowski, S.; Zieliński, P.; Pidek, I.A.; Godlewska, A.; Czubla, P. What was an interglacial river like? Sedimentological investigation of Holsteinian fluvial deposits in eastern Poland. Geol. Q. 2016, 60, 149-166. [CrossRef]

26. Wójcicki, K.J.; Pawelec, H.; Malik, I.; Woskowicz-Ślęzak, B.; Moska, P. Erosion and accumulation phases during the last glacialinterglacial cycle: A case study of the terrace system of the Odra and Osobłoga rivers (southern Poland). Geol. Q. 2020, 64, 104-119. [CrossRef]

27. Kermode, S.J.; Cohen, T.J.; Reinfelds, I.V.; Nanson, G.C.; Pietsch, T.J. Alluvium of antiquity: Polycyclic terraces in a confined bedrock valley. Geomorphology 2012, 139, 471-483. [CrossRef]

28. Keen-Zebert, A.; Hudson, M.R.; Shepherd, S.L.; Thaler, E.A. The effect of lithology on valley width, terrace distribution, and bedload provenance in a tectonically stable catchment with flat-lying stratigraphy. Earth Surf. Process. Landf. 2017, 42, 1573-1587. [CrossRef]

29. Rixhon, G.; Braucher, R.; Bourlès, D.; Siame, L.; Bovy, B.; Demoulin, A. Quaternary river incision in NE Ardennes (Belgium)Insights from ${ }^{10} \mathrm{Be} /{ }^{26} \mathrm{Al}$ dating of river terraces. Quat. Geochronol. 2011, 6, 273-284. [CrossRef]

30. Schaller, M.; Ehlers, T.A.; Stor, T.; Torrent, J.; Lobato, L.; Christl, M.; Vockenhuber, C. Timing of European fluvial terrace formation and incision rates constrained by cosmogenic nuclide dating. Earth Planet. Sci. Lett. 2016, 451, 221-231. [CrossRef]

31. Fikarová, J.; Kř́ženecká, S.; Elznicová, J.; Faměra, M.; Lelková, T.; Matkovič, J.; Matys Grygar, T. Spatial distribution of organic pollutants (PAHs and polar pesticides) in the floodplain of the Ohře (Eger) River, Czech Republic. J. Soils Sediments 2018, 18, 259-275. [CrossRef]

32. Matys Grygar, T.; Elznicová, J.; Lelková, T.; Kiss, T.; Balogh, M.; Strnad, L.; Navrátil, T. Sedimentary archive of contamination in the confined channel of the Ohře River, Czech Republic. J. Soils Sediments 2017, 17, 2596-2609. [CrossRef]

33. Matys Grygar, T.; Bábek, O.; Sedláček, J.; Lend’áková, Z.; Faměra, M.; Štojdl, J.; Pacina, J.; Tolaszová, J.; Kříženecká, S. Segregation and retention of As, potentially toxic metals, and organic pollutants in a reservoir from the Ohře River (the Czech Republic). $J$. Soils Sediments 2020, 20, 2931-2948. [CrossRef]

34. Rajchl, M.; Uličný, D.; Grygar, R.; Mach, K. Evolution of basin architecture in an incipient continental rift: The Cenozoic Most Basin, Eger Graben (Central Europe). Basin Res. 2009, 21, 269-294. [CrossRef]

35. Holodňák, P. Labyrintem Žateckého pravěku (Through Labyrinth of Žatec Prehistory); Studie regionálního muzea v Žatci: Žatec, Czech Republic, 2006; ISBN 80-86971-18-X.

36. Tolksdorf, J.F.; Kaiser, K.; Petr, L.; Herbig, C.; Kočár, P.; Heinrich, S.; Wilke, F.D.H.; Theuerkauf, M.; Fülling, A.; Schubert, M.; et al. Past human impact in a mountain forest: Geoarchaeology of a medieval glass production and charcoal hearth site in the Erzgebirge, Germany. Reg. Environ. Chang. 2020, 20, 1-12. [CrossRef] 
37. Majerová, L.; Bábek, O.; Navrátil, T.; Nováková, T.; Štojdl, J.; Elznicová, J.; Hron, K.; Matys Grygar, T. Dam reservoirs as an efficient trap for historical pollution: The passage of $\mathrm{Hg}$ and $\mathrm{Pb}$ through the Ohře River, Czech Republic. Environ. Earth Sci. 2018, 77, 1-12. [CrossRef]

38. Hošek, M.; Matys Grygar, T.; Elznicová, J.; Faměra, M.; Popelka, J.; Matkovič, J.; Kiss, T. Geochemical mapping in polluted floodplains using in situ X-ray fluorescence analysis, geophysical imaging, and statistics: Surprising complexity of floodplain pollution hotspot. Catena 2018, 171, 632-644. [CrossRef]

39. Rudnick, R.; Gao, S. Composition of the continental crust. In The Crust; Treatise on Geochemistry 3; Rudnick, R.L., Holland, H.D., Turekian, K.K., Eds.; Elsevier-Pergamon: Oxford, UK, 2003; pp. 1-64.

40. Matschullat, J.; Ottenstein, R.; Reiman, C. Geochemical background-Can we calculate it? Environ. Geol. 2000, 39, 990-1000. [CrossRef]

41. Sipos, G.; Kiss, T.; Tóth, O. Constraining the age of floodplain levels along the lower section of River Tisza, Hungary. J. Environ. Geogr. 2016, 9, 39-44. [CrossRef]

42. Tóth, O.; Sipos, G.; Kiss, T.; Bartyik, T. Variation of OSL residual doses in terms of coarse and fine grain modern sediments along the Hungarian section of the Danube. Geochronometria 2017, 44, 319-330. [CrossRef]

43. Murray, A.S.; Wintle, A.G. The single 847 aliquot regenerative dose protocol: Potential for improvements in reliability. Radiat. Meas. 2003, 37, 377-381. [CrossRef]

44. Wintle, A.G.; Murray, A.S. A review of quartz optically stimulated luminescence characteristics and their relevance in singlealiquot regeneration dating protocols. Radiat. Meas. 2006, 41, 369-391. [CrossRef]

45. Galbraith, R.F.; Roberts, R.G.; Laslett, G.M.; Yoshida, H.; Olley, J.M. Optical dating of single and multiple grains of quartz from Jinmium Rock Shelter, northern Australia: Part 1, experimental design and statistical models. Archaeometry 1999, 41, 339-364. [CrossRef]

46. Liritzis, I.; Stamoulis, K.; Papachristodoulou, C.; Ioannides, K. A re-evaluation of radiation dose-rate conversion factors. Mediterr. Archaeol. Archaeom. 2013, 13, 1-15.

47. Brennan, B.J. Beta doses to spherical grains. Radiat. Meas. 2003, 37, 299-303. [CrossRef]

48. Aitken, M.J. Thermoluminescence Dating; Academic Press: London, UK, 1985; p. 351. ISBN 0-12-046380-6.

49. Prescott, J.R.; Hutton, J.T. Cosmic ray contributions to dose rates for luminescence and ESR dating: Large depths and long term variations. Radiat. Meas. 1994, 23, 497-500. [CrossRef]

50. Kiss, T.; Hernesz, P.; Sipos, G. Meander cores on the floodplain-The Early Holocene development of the low-floodplain along the lower Tisza region, Hungary. J. Env. Geogr. 2012, 5, 1-10.

51. Kondolf, G.M. Hungry Water: Effects of dams and gravel mining on river channels. Env. Manag. 1997, 21, 533-551. [CrossRef] [PubMed]

52. Matys Grygar, T.; Mach, K.; Martinez, M. Checklist for the use of potassium concentrations in siliciclastic sediments as paleoenvironmental archives. Sedim. Geol. 2019, 382, 75-84. [CrossRef]

53. Matys Grygar, T.; Popelka, J. Revisiting geochemical methods of distinguishing natural concentrations and pollution by risk elements in fluvial sediments. J. Geochem. Explor. 2016, 170, 39-57. [CrossRef]

54. Kiss, T.; Sümeghy, B.; Sipos, G. Late Quaternary paleodrainage reconstruction of the Maros River alluvial fan. Geomorphology 2014, 204, 49-60. [CrossRef]

55. Kasse, C.; Van Balen, R.T.; Bohncke, S.J.P.; Wallinga, J.; Vreugdenhil, M. Climate and base-level controlled fluvial system change and incision during the last glacial-interglacial transition, Roer River, the Netherlands-Western Germany. Neth. J. Geosci. Geol. Mijnb. 2017, 96, 71-92. [CrossRef]

56. Vandenberghe, J.; Kasse, C.; Popov, D.; Markovic, S.B.; Vandenberghe, D.; Bohncke, S.; Gabris, G. Specifying the external impact on fluvial lowland evolution: The Last Glacial Tisza (Tisa) catchment in Hungary and Serbia. Quaternary 2018, 1, 14. [CrossRef]

57. Vandenberghe, J.; Woo, M.-K. Modern and ancient periglacial river types. Progr. Phys. Geogr. 2002, 26, 479-506. [CrossRef]

58. Dobrzańska, H.; Kalicki, T. Morphology and land use of floodplains in the western part of Sandomierz Basin (southern Poland, Central Europe) in the Roman period. Quat. Intern. 2015, 370, 100-112. [CrossRef]

59. Panin, A.; Adamiec, G.; Buylaert, J.-P.; Matlakhova, E.; Moska, P.; Novenko, E. Two Late Pleistocene climate-driven incision/aggradation rhythms in the middle Dnieper River basin, west-central Russian Plain. Quat. Sci. Rev. 2017, 166, 266-288. [CrossRef]

60. Woolderink, H.A.G.; Kasse, C.; Grooteman, L.P.A.; Van Balen, R.T. Interplay between climatic, tectonic and anthropogenic forcing in the Lower Rhine Graben, the Roer River. Geomorphology 2019, 344, 25-45. [CrossRef]

61. Starkel, L.; Michczyńska, D.J.; Gębica, P.; Kiss, T.; Panin, A.; Perşoiu, I. Climatic fluctuations reflected in the evolution of fluvial systems of Central-Eastern Europe (60-8 ka cal BP). Quat. Intern. 2015, 388, 97-118. [CrossRef]

62. Kadlec, J.; Kocurek, G.; Mohrig, D.; Shinde, D.P.; Murari, M.K.; Varma, V.; Stehlík, F.; Beneš, V.; Singhvi, A.K. Response of fluvial, aeolian, and lacustrine systems to late Pleistocene to Holocene climate change, Lower Moravian Basin, Czech Republic. Geomorphology 2015, 232, 193-208. [CrossRef]

63. Schulte, L.; Julia, R.; Burjachs, F.; Hilgers, A. Middle Pleistocene to Holocene geochronology of the River Aguas terrace sequence (Iberian Peninsula): Fluvial response to Mediterranean environmental change. Geomorphology 2008, 98, 13-33. [CrossRef]

64. Daley, J.S.; Cohen, T.J. Climatically-controlled river terraces in Eastern Australia. Quaternary 2018, 1, 23. [CrossRef] 
65. Kalicki, T.; Frączek, M.; Przepióra, P.; Kusztal, P.; Kłusakiewicz, E.; Malęga, E. Late Quaternary geomorphology and geoarchaeology in the rivers of the Holy Cross Mountains region, central Europe. Quat. Res. 2019, 91, 584-599. [CrossRef]

66. Peng, F.; Prins, M.A.; Kasse, C.; Cohen, K.M.; Van der Putten, N.; van der Lubbe, J.; Toonen, W.H.J.; van Balen, R.T. An improved method for paleoflood reconstruction and flooding phase identification, applied to the Meuse River in the Netherlands. Glob. Planet. Chang. 2019, 177, 213-224. [CrossRef]

67. Lombardi, R.; Davis, L.; Stinchomb, G.E.; Munoz, S.E.; Stewart, L.; Therrell, M.D. Fluvial activity in major river basins of the eastern United States during the Holocene. Holocene 2020, 30, 1279-1295. [CrossRef]

68. Váchová, V. Hodnocení vývoje řeky Ohře mezi obcemi Žatec a Postoloprty (Evaluation of the development of the Ohře River between cities of Žatec and Postoloprty). Master's Thesis, Faculty of Environment, J.E. Purkyně University in Ústí nad Labem, Ústí nad Labem, Czech Republic, 2016.

69. Pacina, J.; Lend'áková, Z.; Štojdl, J.; Matys Grygar, T.; Dolejš, M. Dynamics of Sediments in Reservoir Inflows: A Case Study of the Skalka and Nechranice Reservoirs, Czech Republic. ISPRS Intern. J. Geo-Inf. 2020, 9, 258. [CrossRef]

70. Maßß, A.-L.; Schüttrumpf, H. Reactivation of floodplains in river restorations: Long-term implications on the mobility of floodplain sediment deposits. Water Resour. Res. 2019, 55, 8178-8196. [CrossRef] 